\title{
The periglacial climate and environment in northern Eurasia during the Last Glaciation
}

\author{
Hans W. Hubberten ${ }^{\mathrm{a}, *}$, Andrei Andreev ${ }^{\mathrm{a}}$, Valery I. Astakhov ${ }^{\mathrm{b}}$, Igor Demidov ${ }^{\mathrm{c}}$, \\ Julian A. Dowdeswell ${ }^{\mathrm{d}}$, Mona Henriksen ${ }^{\mathrm{e}}$, Christian Hjort ${ }^{\mathrm{f}}$, Michael Houmark-Nielsen ${ }^{\mathrm{g}}$, \\ Martin Jakobsson $^{\mathrm{h}}$, Svetlana Kuzmina ${ }^{i}$, Eiliv Larsen ${ }^{\mathrm{j}}$, Juha Pekka Lunkkak ${ }^{\mathrm{k}}$, Astrid Lysåj, \\ Jan Mangerud $^{\mathrm{e}}$, Per Möller ${ }^{\mathrm{f}}$, Matti Saarnisto ${ }^{1}$, Lutz Schirrmeister ${ }^{\mathrm{a}}$, Andrei V. Sher ${ }^{\mathrm{m}}$, \\ Christine Siegert $^{\mathrm{a}}$, Martin J. Siegert ${ }^{\mathrm{n}}$, John Inge Svendsen ${ }^{\mathrm{o}}$ \\ a Alfred Wegener Institute for Polar and Marine Research (AWI), Telegrafenberg A43, Potsdam D-14473, Germany \\ ${ }^{\mathrm{b}}$ Geological Faculty, St. Petersburg University, Universitetskaya 719, St. Petersburg 199034, Russian Federation \\ ${ }^{\mathrm{c}}$ Institute of Geology, Karelian Branch of Russian Academy of Sciences, Pushkinskaya 11, Petrozavodsk 125610, Russian Federation \\ ${ }^{\mathrm{d}}$ Scott Polar Research Institute and Department of Geography, University of Cambridge, Cambridge CBZ IER, UK \\ ${ }^{\mathrm{e}}$ Department of Earth Science, University of Bergen, Allégt. 41, Bergen N-5007, Norway \\ ${ }^{\mathrm{f}}$ Quaternary Science, Department of Geology, Lund University, Geocenter II, Sölvegatan 12, Lund Sweden \\ ${ }^{\mathrm{g}}$ Geological Institute, University of Copenhagen, Øster Voldgade 10, Copenhagen DK-1350, Denmark \\ ${ }^{\mathrm{h}}$ Center for Coastal and Ocean Mapping, Chase Ocean Engineering Lab, University of New Hampshire, Durham, NH 03824, USA

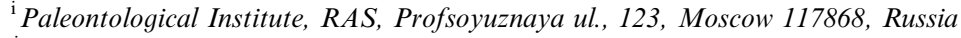 \\ ${ }^{\mathrm{j}}$ Geological Survey of Norway, PO Box 3006 Lade, Trondheim N-7002, Norway \\ ${ }^{\mathrm{k}}$ Institute of Geosciences, University of Oulu, PO Box 3000, Linnanmaa FIN-90014, Finland \\ ${ }^{1}$ Geological Survey of Finland, Betonimiehenkuja 4, PO Box 96, Espoo FI-02151, Uusimaa, Finland \\ ${ }^{\mathrm{m}}$ Severtsov Institute of Ecology and Evolution, RAS, Leninskiy Prospect, 33, Moscow 119071, Russia \\ ${ }^{\mathrm{n}}$ Bristol Glaciology Centre, School of Geographical Sciences, University of Bristol, Bristol BS8 ISS, UK \\ ${ }^{\circ}$ Department of Geology, Allègt. 41, Bergen N-5007, Norway
}

\begin{abstract}
This paper summarizes the results of studies of the Late Weichselian periglacial environments carried out in key areas of northern Eurasia by several QUEEN teams (European Science Foundation (ESF) programme: "Quaternary Environment of the Eurasian North"). The palaeoglaciological boundary conditions are defined by geological data on timing and extent of the last glaciation obtained in the course of the EU funded project "Eurasian Ice Sheets". These data prove beyond any doubt, that with the exception of the northwestern fringe of the Taymyr Peninsula, the rest of the Eurasian mainland and Severnaya Zemlya were not affected by the Barents-Kara Sea Ice Sheet during the Last Glacial Maximum (LGM).

Inversed modelling based on these results shows that a progressive cooling which started around 30 ka BP, caused ice growth in Scandinavia and the northwestern areas of the Barents-Kara Sea shelf, due to a maritime climate with relatively high precipitation along the western flank of the developing ice sheets. In the rest of the Eurasian Arctic extremely low precipitation rates (less than $50 \mathrm{~mm} \mathrm{yr}^{-1}$ ), did not allow ice sheet growth in spite of the very cold temperatures. Palaeoclimatic and palaeoenvironmental conditions for the time prior to, during, and after the LGM have been reconstructed for the non-glaciated areas around the LGM ice sheet with the use of faunal and vegetation records, permafrost, eolian sediments, alluvial deposits and other evidences. The changing environment, from interstadial conditions around $30 \mathrm{ka}$ BP to a much colder and drier environment at the culmination of the LGM at 20-15 ka BP, and the beginning of warming around $15 \mathrm{ka}$ BP have been elaborated from the field data, which fits well with the modelling results.
\end{abstract}

(C) 2003 Elsevier Ltd. All rights reserved.

*Corresponding author. Fax: +49-331-2882-137.

E-mail address: hubbert@awi-potsdam.de (H.W. Hubberten).

\section{Introduction}

Major progress has been made during recent years in understanding the timing and extension of the Weichselian glaciations of Eurasia. Based on comprehensive 
geological investigations, a new reconstruction of the Eurasian Ice Sheets has been presented for the Last Glacial Maximum (LGM) at about 18-20,000 years ago (Fig. 1 from Svendsen et al., 2004b). According to this reconstruction the northwestern fringe of the Taymyr Peninsula was affected by a restricted ice advance from the Kara Sea, but the eastern part of the Eurasian mainland and Severnaya Zemlya was not ice-covered during the LGM. Thus, the ice sheet was much smaller during this period than suggested by several previous reconstructions, which have shown a large ice mass $2 \mathrm{~km}$ thick located over most of the Eurasian Arctic (e.g. Denton and Hughes, 1981; Hughes, 1985; Grosswald and Hughes, 1995, 2002; Grosswald, 1998).

In this paper, we present our current knowledge of the periglacial environment and climatic conditions in northern Eurasia during the build-up, culmination, and waning of the LGM ice sheets, based on proxy data from the north of western Russia and Siberia and on glaciological modelling. The geological records indicate that the continental shelves in the Eurasian Arctic were basically free of glaciers at the end of the Middle Weichselian (Mangerud et al., 1998; Bauch et al., 2001; Kleiber et al., 2001; Knies et al., 2001; Stein et al., 2001), which implies that the Barents-Kara Sea Ice Sheet, as it appeared at the LGM, formed during a relatively short period of time (Mangerud et al., 1999; Alexanderson et al., 2001; Gataullin et al., 2001). The eastern flank of the Scandinavian Ice Sheet advanced a $1000 \mathrm{~km}$ during this period (e.g. Lunkka et al., 2001). This rapid build-up of glacier ice represents a response to a rapid shift in the climate system, which in turn must also have modified the environment in the ice-free western part of northern Russian and Siberia.

A three-dimensional ice-sheet reconstruction for the LGM, forced to fit the new geological constraints on the ice sheet extent over the Eurasian Arctic, has been generated using inverse modelling (Siegert et al., 1999, 2001). From these model experiments, specific climatic parameters (mean-annual precipitation and air temperature) were defined for the land areas along the eastern and southern borders of the ice sheet. The results were subsequently compared with geological records containing information on climate in the different study areas.

Both published and unpublished data from our field studies are used to reconstruct the palaeoclimate in the areas beyond the ice fronts (Fig. 1). Various types of information are used to characterize the terrestrial environment, including faunal and vegetation records, the distribution of permafrost, aeolian sediments and alluvial deposits. We have also incorporated results from some previous projects into this synthesis. Palaeoclimatic data used for our present reconstruction are obtained from numerical modelling and from field observations in the following areas, arranged from east to west (cf. Fig. 1).

\section{Results}

\subsection{LGM climate inferred from numerical simulations of the Eurasian Ice Sheets}

Siegert et al. $(1999,2001)$ used a numerical ice-sheet model linked to a simple climate model to reconstruct the Barents-Kara Sea Ice Sheet as constrained by the geologically mapped ice margins (Svendsen et al., 1999, 2004b). An inverse procedure was employed in which the ice-sheet model's climate inputs (mean-annual precipitation and air temperature) were adjusted until a 'fit' between the model results and the geological evidence was established (Siegert and Marsiat, 2001).

The ice-sheet model is based on the flow law for ice (Glen, 1955). Ice streams were modelled in bathymetric troughs by accounting for the reduction in effective ice pressure due to ice buoyancy in water (e.g. Bentley, 1987). Several ice-sheet models based on these principles are available, and intercomparison experiments indicate that such models provide similar results on a continental scale (Huybrechts et al., 1996). Details of the ice-sheet model are provided by Siegert et al. (1999). The model requires time-dependent inputs of ice accumulation and surface air-temperature from a climate model that is linked to the ice sheet (Dowdeswell and Siegert, 1999; Siegert et al., 1999).

The model produces an ice dome $2.5 \mathrm{~km}$ thick over Scandinavia, slightly higher than predicted by the ICE4G isostatic model of the same region (Peltier, 1994). Across the Barents Sea the ice sheet was only $1200 \mathrm{~m}$ thick. Fast-flowing ice streams occupying bathymetric troughs drained ice from the central Barents Sea, and this caused the ice thickness to be generally low (Fig. 2). The entire western margin of the Barents Sea was glaciated at the LGM (Landvik et al., 1998). The eastern margin of the ice sheet was situated within the Kara Sea. No glacier was formed on the Taymyr Peninsula, and there was limited glacier growth on Severnaya Zemlya (Fig. 2). The marine margins of the ice sheet lost ice through iceberg calving, predominantly at the mouths of bathymetric troughs where the ice streams terminated. However, the dominant wastage process along the southern margin of the ice sheet was surface melting.

The LGM palaeoenvironment implied by the ice-sheet model is characterized by a maritime climate across the western ice-sheet margin and by extreme polar desert conditions towards the east (Fig. 2). Specifically, rates of ice accumulation of over $600 \mathrm{~mm} \mathrm{yr}^{-1}$ are calculated across the western margin of Scandinavia. The meanannual surface air-temperature in this region was $-5^{\circ} \mathrm{C}$ (similar to Svalbard today). At the western margin of the Barents Sea the rate of accumulation was between 200 and $100 \mathrm{~mm} \mathrm{yr}^{-1}$ and the mean-annual air temperature was around $-20^{\circ} \mathrm{C}$. Farther east ice accumulated had an extremely low rate (i.e. $<50 \mathrm{~mm} \mathrm{yr}^{-1}$ ). On the 


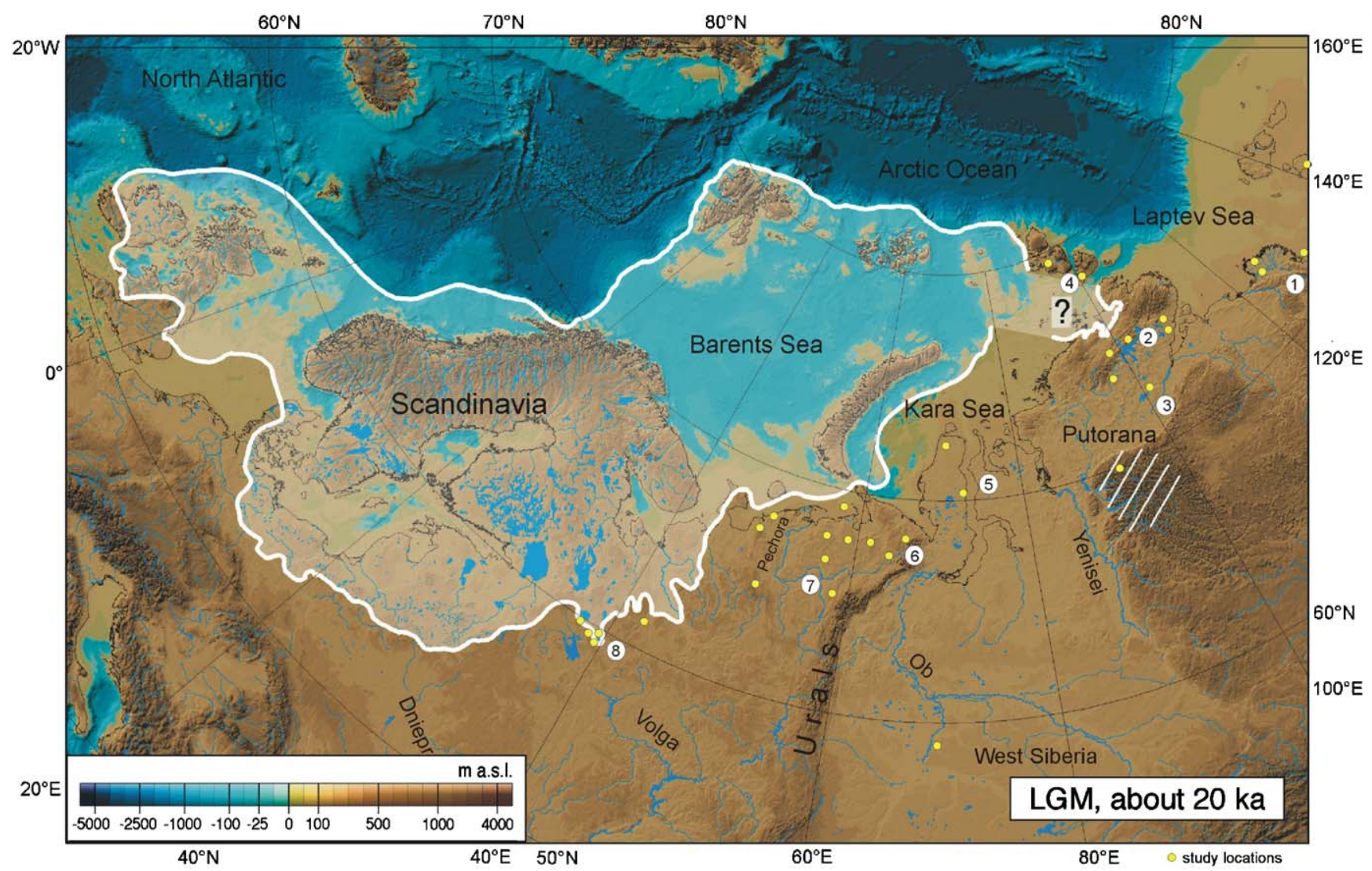

Fig. 1. Map showing the LGM Eurasian Ice Sheet according to Svendsen et al. (2004b), with the numbered working areas described in the text. (1) Laptev Sea Coast and Bykovsky Peninsula, (2) Central Taymyr Peninsula, (3) SE Taymyr Peninsula, Labaz Lake Region, (4) Severnaya Zemlya Archipelago, (5) West Siberia and Yamal Peninsula, (6) Ural Mountains, (7) Pechora Lowland, and (8) NW Russian Plain.

Taymyr Peninsula precipitation was reduced to zero, and according to this model no ice sheet was build-up here or anywhere farther east across the Eurasian Arctic was curtailed.

The southern margin of the ice sheet was affected by surface ablation, implying warmer mean-annual air temperatures here and therefore a considerable $\mathrm{N}-\mathrm{S}$ temperature gradient from the Arctic islands to mainland Russia. However, the ice-sheet model calculates mean-annual temperatures that do not preclude permafrost across the periglacial region, or extreme cold events during the wintertime across this zone.

Results from a sophisticated atmospheric general circulation model (AGCM) were used to ascertain the relative importance of these climatic processes (Siegert and Marsiat, in press). The LGM palaeoclimate developed by the AGCM (Fig. 3) shows a distribution of mean-annual ice accumulation and air temperature similar to that established from the ice-sheet model. The major difference is that the AGCM indicates much colder conditions across the Kara Sea (mean-annual air temperature less than $-35^{\circ} \mathrm{C}$ ). Although air temperatures simulated by the two models are similar over the southwestern part of the Scandinavian Ice Sheet, colder conditions are calculated by the AGCM across the northeastern half of the ice sheet. Mass balance calculations (Fig. 3) are in close agreement with those established from the ice-sheet model (Fig. 2). For example, high net accumulation rates (over $500 \mathrm{~mm} \mathrm{yr}^{-1}$ ) are simulated by both models along the southwestern part of the ice sheet. These high rates of ice accumulation decrease northwards along the Atlantic Coast and eastwards across the Scandinavian Ice Sheet. At the western margin of the Barents Sea the rate of ice accumulation was calculated at around $280 \mathrm{~mm} \mathrm{yr}^{-1}$, compared with $300 \mathrm{~mm} \mathrm{yr}^{-1}$ in the ice-sheet model (Figs. 2 and 3). From the western Barents Sea margin, iceaccumulation rates decreased rapidly towards the east across the Barents Sea and Kara Sea Ice Sheets. Over the centre of the Barents Sea Ice Sheet, the AGCM model calculates ice-accumulation rates between 280 and $120 \mathrm{~mm} \mathrm{yr}^{-1}$. This compares well with the ice-sheet model's prediction of ice-accumulation rates between 300 and $100 \mathrm{~mm} \mathrm{yr}^{-1}$. Farther east, extreme polar desert conditions are simulated over the Kara Sea Ice Sheet, where the accumulation rate of ice was as low as $40 \mathrm{~mm} \mathrm{yr}^{-1}$. Again, this compares favourably with the ice-sheet model results, in which the ice-accumulation 


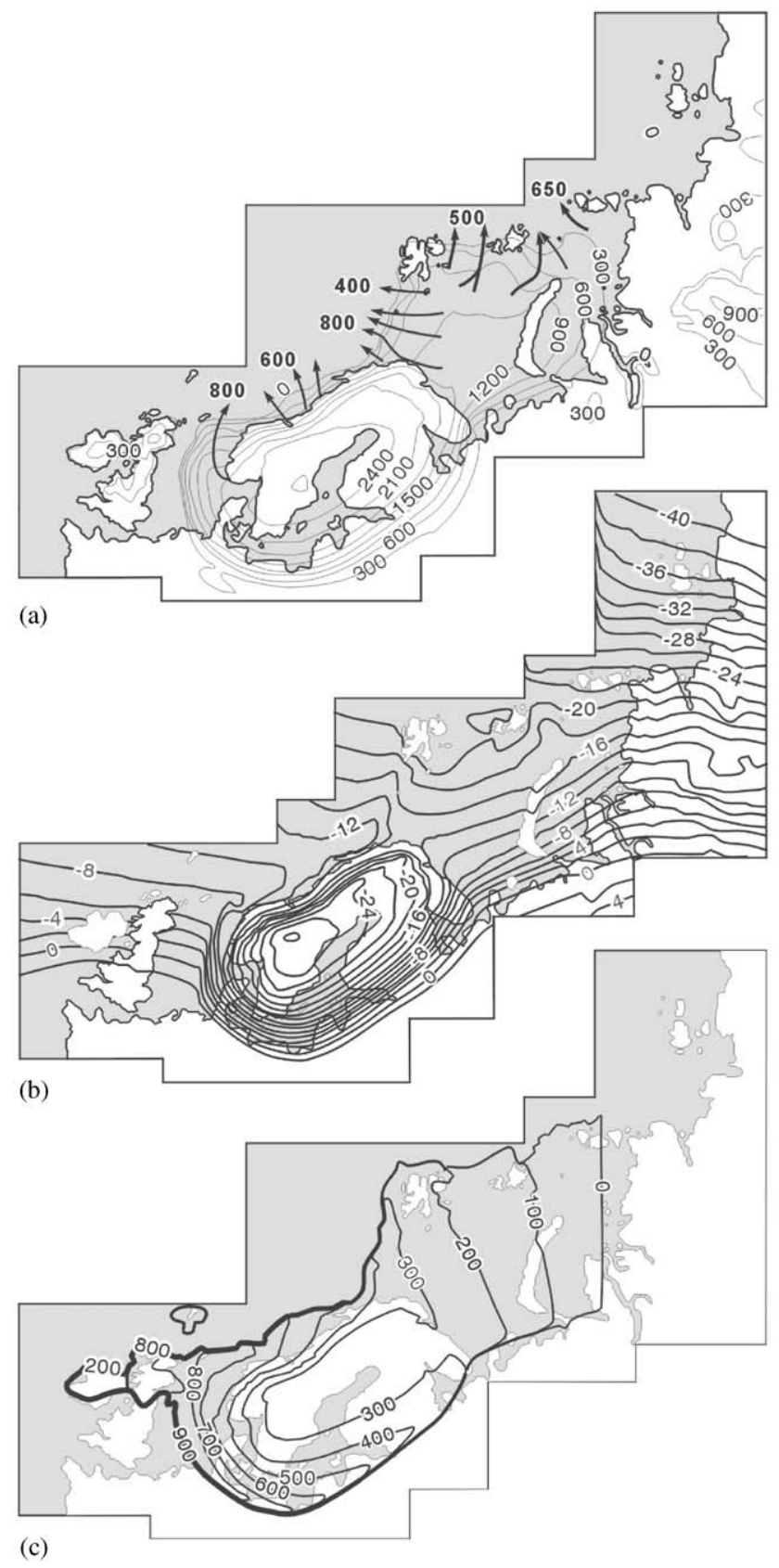

Fig. 2. LGM Eurasian Ice Sheet and climate based on numerical icesheet modelling: (a) ice-sheet topography (contours every $300 \mathrm{~m}$ ); (b) mean-annual surface air-temperature $\left({ }^{\circ} \mathrm{C}\right)$; and (c) mean-annual rates of ice accumulation (water equivalent $\mathrm{mm} \mathrm{yr}^{-1}$ ). After Siegert et al. (1999).

rate here was between 100 and $0 \mathrm{~mm} \mathrm{yr}^{-1}$. However, the ACGM model gives a slightly higher accumulation figure for the northwest coast of Taymyr, which was affected by a limited LGM ice sheet.

The ACGM calculates a full range of climate parameters. These can be used to infer details about the climatic conditions associated with the Eurasian Ice Sheets at the LGM (Fig. 4). The atmospheric circulation over the Atlantic Ocean was split into two branches.

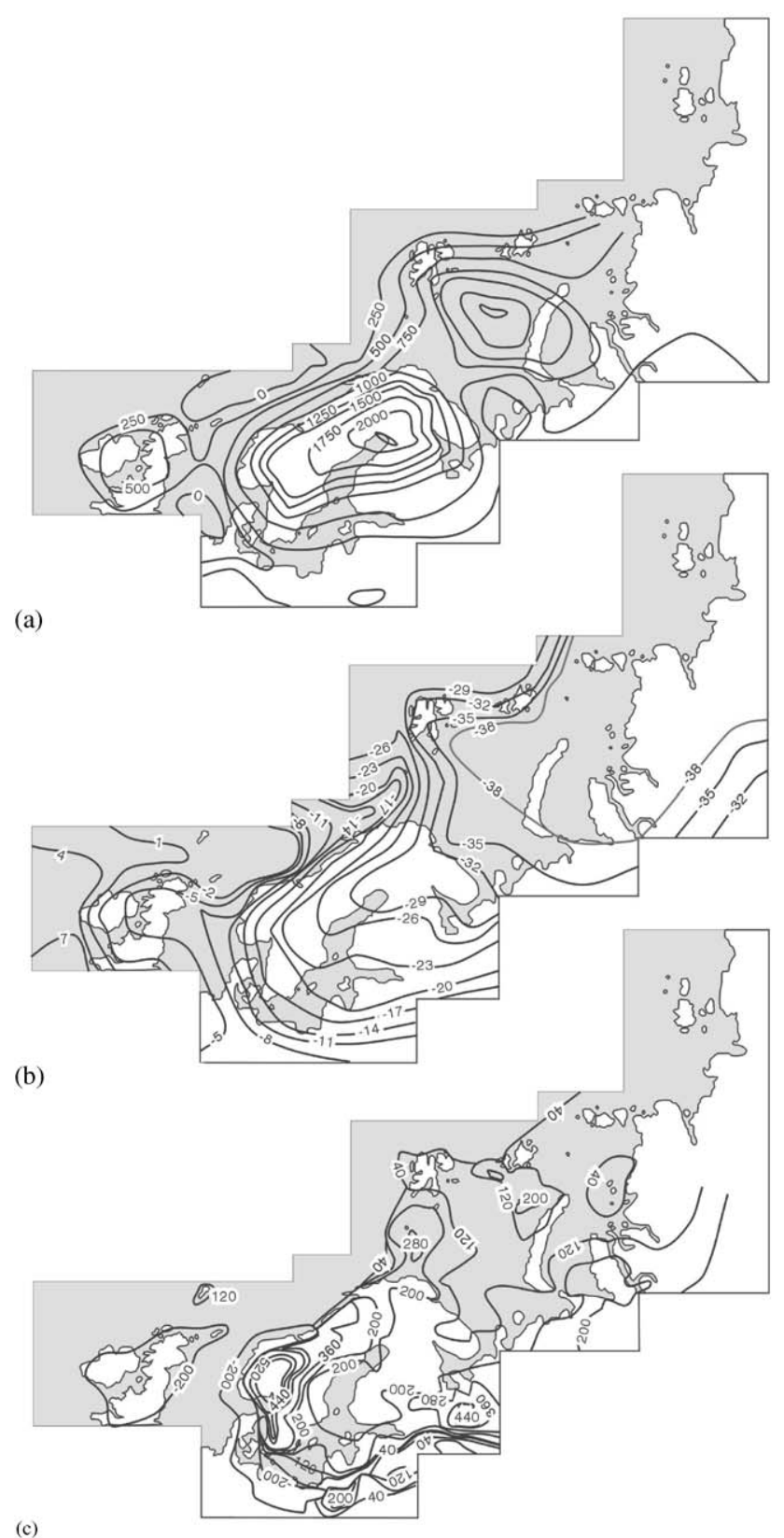

Fig. 3. AGCM palaeoclimate results for the LGM Eurasian Ice Sheet depicted in the ICE-4G reconstruction of Peltier (1994): (a) ice-sheet topography (contours every $250 \mathrm{~m}$ ); (b) mean-annual temperature $\left({ }^{\circ} \mathrm{C}\right)$; and (c) annual rate of ice accumulation (water equivalent $\mathrm{mm} \mathrm{yr}^{-1}$ ). After Siegert and Marsiat (2001).

Part of the warm air was directed towards the northern part of the oceanic basin, whilst a much weaker flux of heat entered the Eurasian continent. However, these warm winds were not deflected northwards across the Eurasian Arctic but instead followed the Mediterranean coast towards Central Europe. The southeastern margin of the Eurasian Ice Sheet and northwest Siberia were under the flow of cold and dry winds coming off the Scandinavian Ice Sheet, resulting in polar desert 


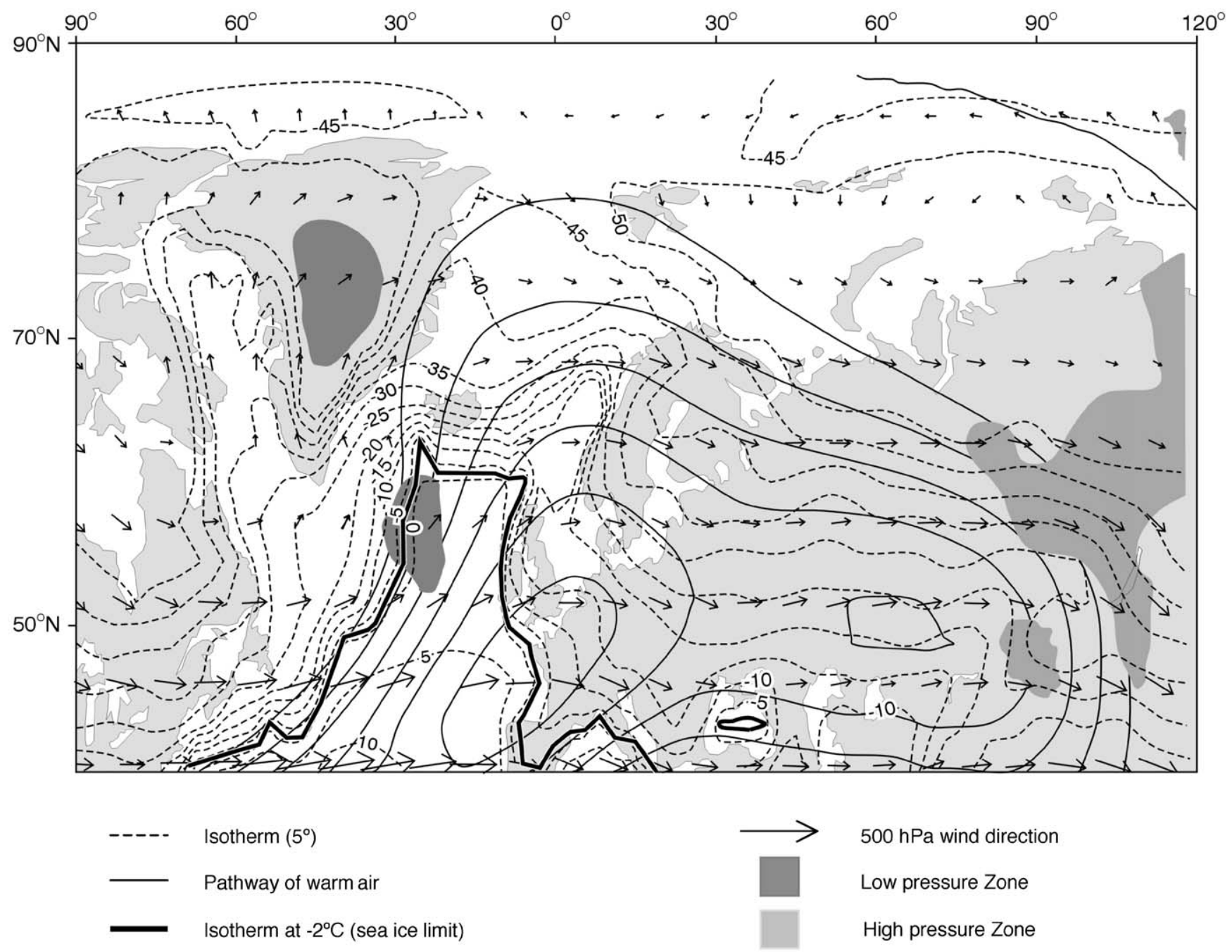

Fig. 4. AGCM meteorological conditions associated with the ice-sheet mass balance and air temperatures presented in Fig. 2 (from Siegert and Marsiat, 2000). Note that the 'Pathway of warm air' represents the positive anomalies of the departure of the $250 \mathrm{hPa}$ stream function from the zonal average.

conditions across the Kara Sea and the Taymyr Peninsula. The Kara Sea region was also influenced by a stable anticyclonic flow of air, which further isolated the region climatically. The air moves across an ice sheet, so the atmosphere cannot acquire moisture, leading to a long-term condition of cold dry air in this region. This led to a significantly reduced precipitation pattern, not only over the Kara Sea but also farther east across the Laptev Sea, compared with the present day. It was this reduction in precipitation that curtailed the growth of any significant ice cover east of Novaya Zemlya (Fig. 1).

\subsection{LGM climate inferred from geological evidence}

\subsubsection{Laptev Sea Coast, Bykovsky Peninsula}

The Late Quaternary environmental history of the Laptev Sea region has been studied on the east coast of the
Bykovsky Peninsula, southeast of the Lena Delta (Locality 1, Fig. 1). Permafrost deposits with large syngenetic ice wedges, the so-called Ice Complex and associated thermokarst deposits, have preserved many traces of the Pleistocene and Holocene environment and contain an almost continuous record of the vegetation and fauna at least 50-60,000 years back in time (Schirrmeister et al., 2002a). Heavy mineral analyses indicate that most of the sand and silt in the Ice Complex deposits and younger thermokarst deposits are derived from the neighbouring Kharaulakh Mountains, the northernmost part of the Verkhoyansk Mountains (Siegert et al., 2002). This implies that the Kharaulakh Mountains were not covered by an ice cap but were exposed to subaerial denudation throughout the last ca 60,000 years.

The environmental changes from the Middle to the Late Weichselian and into the Holocene have been reconstructed from the results of multidisciplinary 
research (1998-2002) on the Bykovsky Peninsula sequence. The two most evident results are (1) the continuous existence of a treeless grass/herb-dominated vegetation (Andreev et al., 2002b), and (2) very cold winters, evidenced by continuous growth of thick ice wedges and by their stable-isotope composition. The syngenetic ice wedges of the Bykovsky Ice Complex predating the LGM (50-20 ka BP) show relatively constant mean hydrogen and oxygen-isotope composition around $-240 \%$ and $-30 \%$, respectively, indicating much colder winters than presently (Fig. 5; Meyer et al., 2002a). In Holocene ice wedges of this area stableisotope values vary around $-200 \%$ for $\delta \mathrm{D}$ and $-26 \%$ for $\delta^{18} \mathrm{O}$. A first estimate gave winter temperatures during pre LGM ice complex formation, of approximately $7^{\circ} \mathrm{C}$ lower than today (Meyer et al., in preparation). The time-related variations in this environment are revealed by a detailed record of fossil-insect assemblages (Fig. 6); (Kuzmina, 2001; Sher et al., in preparation).

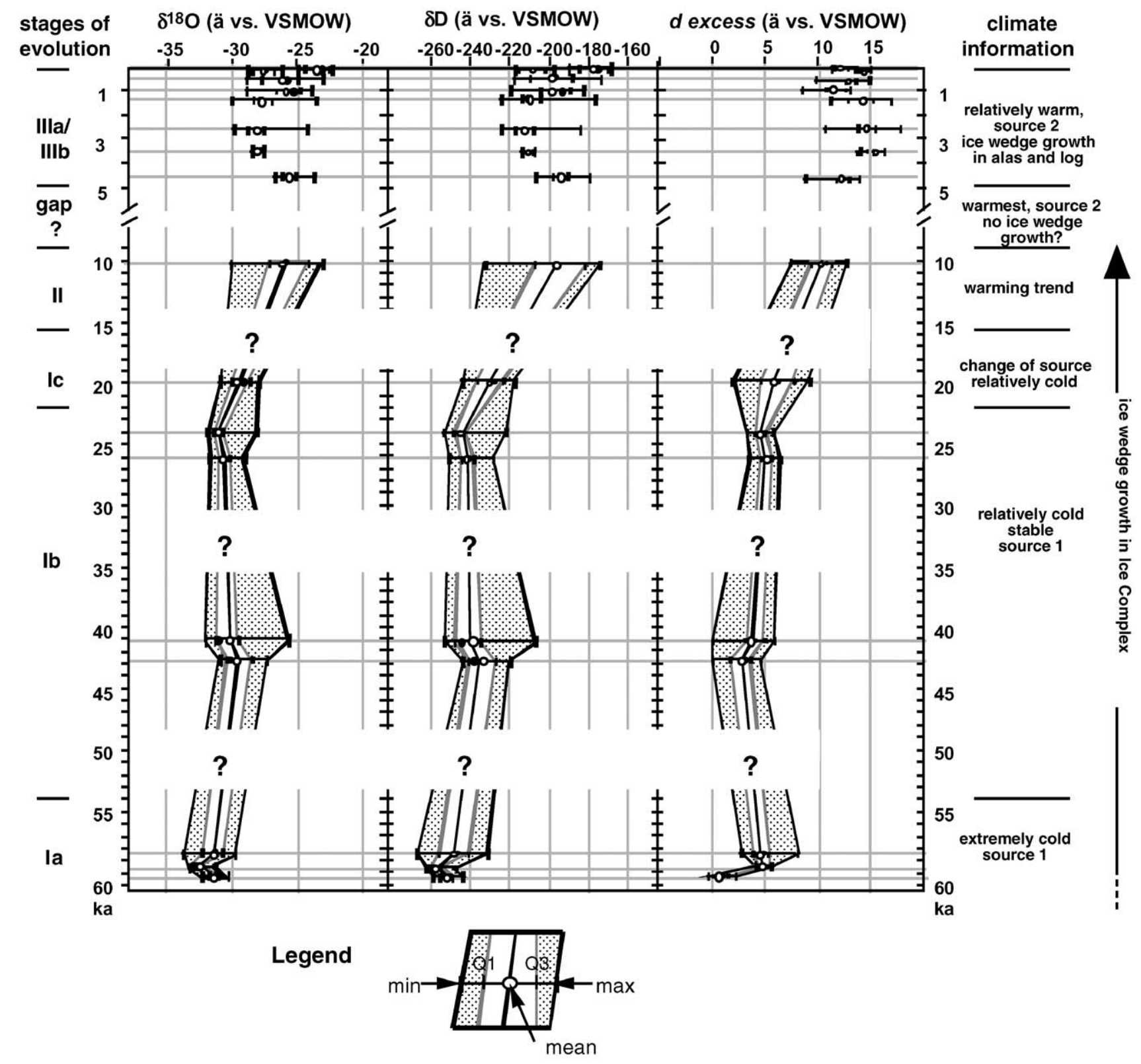

Fig. 5. Development of $\delta^{18} \mathrm{O}, \delta \mathrm{D}$ and d excess for Ice Complex ice wedges and Holocene ice wedges of the Bykovsky Peninsula through time. White dots represent the mean isotopic composition and black dots represent the median of horizontal transects. A straight black line follows the development of the mean isotopic composition through time. The respective range (grey field) and an intermediate area (white field) between the quartiles Q1 and Q3 (dotted lines) are held out for visualization. White gaps were left where no ice wedges were sampled. Sources 1 and 2 describes two different moisture sources as reconstructed from the d excess. (For more detailed Information, see Meyer et al., 2002a.) 

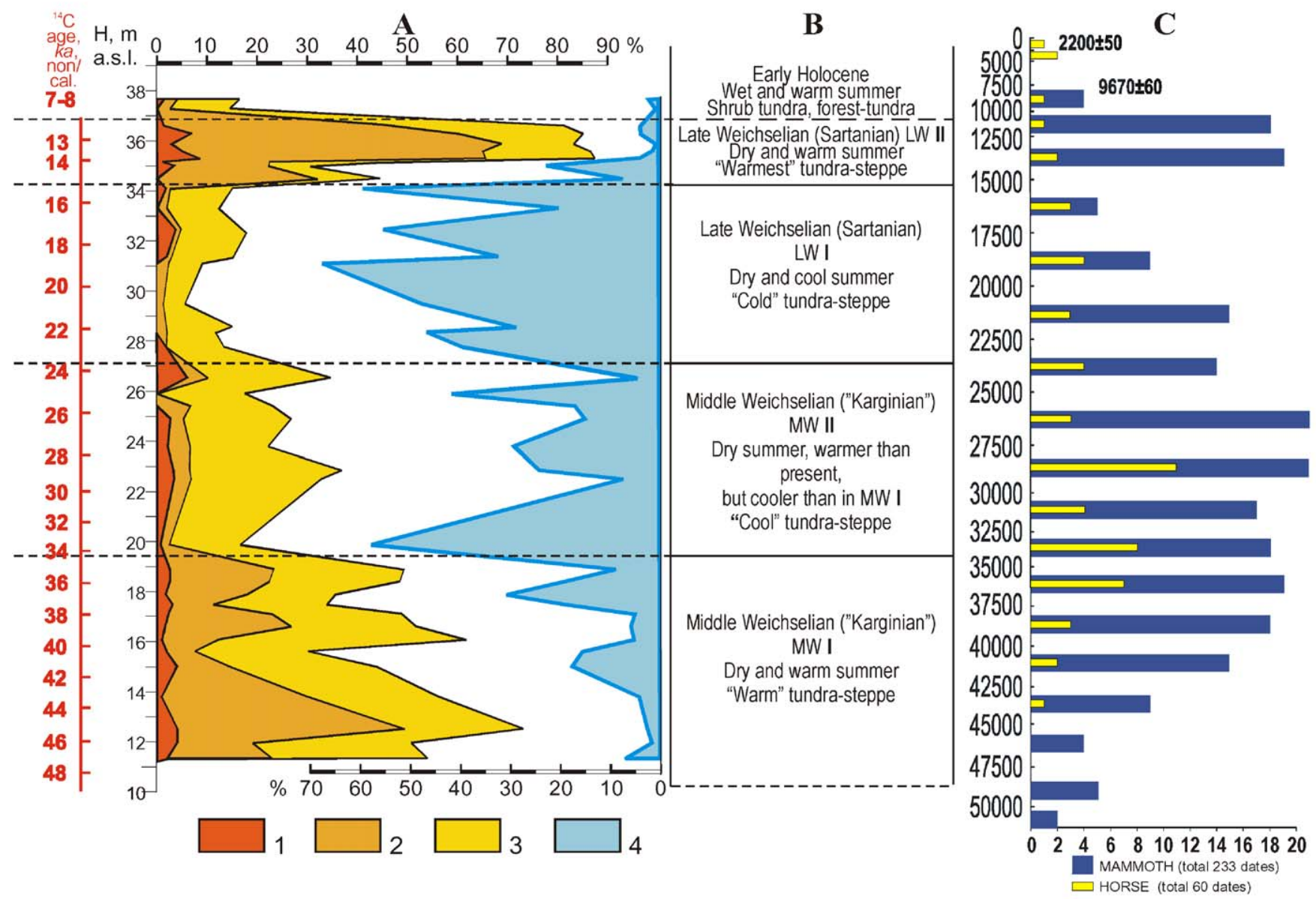

Fig. 6. Summer climate changes and the dated record of mammals in the Laptev Sea area (from Sher et al., in preparation). (a) Fossil-insect record in the Mamontovy Khayata section, Bykovsky Peninsula. Percentage of selected ecological groups of insects (minimum number of individuals in each sample equals 100\%): Thermophilous xerophiles: 1 -steppe species; 2 - other xerophilous insects (except tundra ones); Insects, currently common in tundra: 3- dry tundra inhabitants (prefer warmer sites); 4-Arctic tundra insects (plotted from the right axis). ${ }^{14} \mathrm{C}$ ages in the left column are calculated from two separate regression equations after about 40 AMS dates. (b) Climatic and environmental interpretation of the insect assemblages from the Mamontovy Khayata section. (c) Radiocarbon dates of mammal bones from the Laptev Sea area (number of dates in 2500-year intervals). The latest available dates for mammoth and horse are indicated at the top.

The earlier part of the Middle Weichselian (ca 46$34 \mathrm{ka}$ BP) was marked by high abundance of insects living in warm and dry habitats, including steppe species, and a relatively low proportion of high Arctic species. That implies that summer temperature was higher than present. A higher plant species diversity (mostly in herbs), inferred from radiocarbon-dated pollen spectra (Andreev et al., 2002b) and plant macrofossils (Kienast, 2002), also suggests more favourable summer conditions during that period. Although water was the main depositional agent of the sediment, the environment was rather dry during most of the summer, and the soil was better heated than in the modern tundra. This is confirmed by the study of soil rhizopods (testate amoebae) (Bobrov et al., 2003). The mosaic of habitats included both extremely dry and more mesic (boggy) ones, as well as small ponds (where peat beds accumulated) which, however, were less common than today. The small water bodies were well heated in summer, indicated by the presence of thermophilic species among water plants, currently known only from more southern areas. In general, the environment of that time can be characterized as a relatively "warm" variant of tundra-steppe.

According to the fossil/insect record, the latter half of the Middle Weichselian (ca 34-24 ka BP) was characterized by a distinct lower level of thermophilic xerophiles, while the role of dry tundra inhabitants remained important, but there was a marked increase in the relative abundance of Arctic tundra species (Fig. 6). This indicates cooler summers than before, although the temperature remained high enough for the survival of steppe species. That is in agreement with the plantmacrofossil evidence, suggesting dry and relatively warm summer conditions until at least $25 \mathrm{ka}$ BP, 
although vegetation cover was probably sparser (Schirrmeister et al., 2002b).

Most of the Late Weichselian (Sartanian), namely from about 24 to $15 \mathrm{ka} \mathrm{BP}$, was characterized by the lowest levels of xerophilic insects, virtual disappearance of steppe species, and dominance of Arctic tundra inhabitants (Fig. 6). That definitely indicates lower summer temperatures than in the Middle Weichselian, but still warmer temperatures than today are indicated by the occurrence of some thermophilic plant species (Kienast, 2002). At the same time, the environment remained very dry, as evidenced by various proxy data (Schirrmeister et al., 2002b). Palaeobotanical data indicate that the grass/herb-dominated vegetation cover became discontinuous. Thus, the period corresponding to the LGM was marked in this area by high aridity and relatively low summer temperature. The environment of that time can be regarded as the cold variant of tundrasteppe.

A sharp increase in summer temperature marks the latest Weichselian (Sartanian), from about 15 to $12.5 \mathrm{ka}$ BP. The proportion of all groups of insects preferring warm and dry habitats, jumps to levels even higher than in the Middle Weichselian ("warm" tundra-steppe). It is possible that this abrupt change in summer temperature triggered the regional outburst of thermokarst processes, which, in turn pushed forward by the Pleistocene/ Holocene environmental revolution, resulted in the dramatic turnover of dry grassland into modern boggy tundra with a huge number of thermokarst lakes.

All kinds of proxy evidence - both biological (insects, pollen, plant macrofossils, soil microfauna) and sedimentological - depict the Early Holocene environment as completely different from that of the Pleistocene. Many lines of evidence agree in pointing to increasing humidity during the so-called "Early Holocene Climatic Optimum", when the temperature of the growing season was higher than present.

In both the Middle and Late Weichselian, environments in the Laptev Sea region were favourable for large grazing mammals, such as mammoth (Mammuthus primigenius), horse (Equus caballus) and bison (Bison priscus). The collection of ${ }^{14} \mathrm{C}$ dates on mammal bones from the region (from Central Taymyr Peninsula to the Khroma River valley and the Arctic islands) has amounted to 380 dates, obtained in the course of the Russian-German Expedition and from various published sources; 233 of them are for mammoths, while other species received many fewer dates (including about 60 for horses, 40 for muskox, and 30 for bison) and do not provide statistically reliable series (Sher et al., 2003, in preparation). The distribution of the number of mammoth dates against the timescale can be seen (Fig. 6). The number of finite dates on bones older than $40-42 \mathrm{ka}$ BP is generally low (average 2.8 dates per 1000 years) for technical reasons (infinite dates are not considered). After that time, the number of dated mammoth bones is more or less high (av. 7.6 per 1000 years) until about $25 \mathrm{ka}$ BP. Then it starts to decrease progressively during the Late Weichselian with a minimum at $16-17 \mathrm{ka}$ BP ( 2 dates). It should be noted, however, that even during the peak of the LGM (18$20 \mathrm{ka} \mathrm{BP}$ ) mammoth still inhabited the whole area of the Laptev Shelf Land, including the present northernmost islands and Severnaya Zemlya. The number of mammoth dates sharply jumps up after $15 \mathrm{ka} \mathrm{BP}$, and stays at high levels (av. 7.4 in 1000 years) until $10 \mathrm{ka} \mathrm{BP}$. This period (the Late Sartanian) was the last interval with abundant dated records of woolly mammoth (the latest dated mammoth fossils in the region come from the interval $10-9.6 \mathrm{ka} \mathrm{BP}$, and are so far known from the Taymyr Peninsula only).

The chronological variation in the number of radiocarbon dates is subject to many factors. Nevertheless, the analysis of spatial distribution of dated bones, possible changes in taphonomy and other random factors allows various authors (Sulerzhitsky and Romanenko, 1999; Kuznetsova et al., 2001; Sher et al., 2003) to assume that the chronological distribution of dates may broadly reflect relative numbers of animals in the past. Both of the peaks in the number of mammoth dates in the Laptev Sea collection correspond to periods with a relatively high proportion of xerophilic insects and the presence of steppe species (Fig. 6). A high diversity of insect fauna implies a richer vegetation mosaic, including more extensive areas with better heat supply, occupied by presumably more productive grassland. The number of mammoth dates starts to decrease at the same time as the proportions of those insect groups, reaching its lowest point soon after the period of total absence of steppe species. This pattern allows us to infer that all varieties of tundra-steppe insect assemblages indicate environments tolerable to the woolly mammoth, but that the less diverse insect faunas of the LGM, lacking the most thermophilic beetle species, may suggest less productive, probably just sparser, vegetation, and large grazers seem to have responded by reducing their numbers.

\subsubsection{Taymyr Peninsula}

The Taymyr Peninsula (Localities 2 and 3, Fig. 1) is presently situated at the edge of the Siberian anticyclone (Atlas Arktiki, 1985 and Fig. 4) and this region thus is either influenced by Atlantic air masses or by the anticyclone. This transitional position of the Taymyr region is expressed in its glaciation history and environmental development.

A series of radiocarbon data from permafrost deposits with thick polygonal ice wedges on the northwestern shore of Lake Taymyr indicates glacier-free conditions in this area since at least $30 \mathrm{ka}$ BP (Isayeva and Kind, 1982; Pavlidis et al., 1997; Möller et al., 
1999). Other investigations have also indicated that the extent of glaciers during the LGM have been noticeably smaller than during earlier glacial periods (Isayeva et al., 1993; Alexanderson et al., 2001, 2002). Data on the temporal distribution of mammal-bone remains on the Taymyr Peninsula (Sulerzhitsky, 1995; Sulerzhitsky and Romanenko, 1999) are in good agreement with this assumption. In general, it has been shown that mammoths apparently existed in the area from around 50,000 years up to the beginning of the Holocene. The presence of horses at the same time indicates an extreme continental climate with a limited snow cover.

In order to verify these findings, detailed studies on well-dated sequences on the Taymyr Peninsula were undertaken during the last decade and are summarized below. A key site is Cape Sabler, situated on the northwestern shore of Taymyr Lake (Fig. 1). Sections here expose sediment successions of laminated silts and fine sands up to $30 \mathrm{~m}$ thick, often rich in plant detritus and with thick beds of silt-soaked peat (Möller et al., 1999). The sequences were first interpreted as lacustrine deposits, however, a more likely interpretation (Möller, in preparation) is that the lower part of the sequence represents vertical accretion in a terrestrial environment, with peat-bog and aeolian deposition and syngenetic formation of ground-ice polygons (Siegert et al., 1999), which were temporarily flooded by the lake during the annual snow melt (the present annual lake amplitude is $5 \mathrm{~m})$. New AMS ${ }^{14} \mathrm{C}$ dates obtained from Cape Sabler, and also from nearby localities with the same type of sediments, suggest continuous deposition from more than $35 \mathrm{ka}$ BP to the Holocene (Fig. 7). An increasing sedimentation rate at Cape Sabler around $19 \mathrm{ka}$ BP (Möller et al., 1999) is probably connected with an LGM ice advance inundating the northwesternmost part of the Taymyr Peninsula (Alexanderson et al., 2001, 2002; Svendsen et al., 2004b), thus reversing the drainage direction of the Taymyra river.

In the Labaz Lake area permafrost deposits rich in syngenetic and epigenetic ice wedges accumulated between 45 and $15 \mathrm{ka}$ BP (Siegert et al., 1999). In conformity with the results from the Laptev Sea Coast, the stable-isotope composition of ice wedges from the Labaz Lake area (Fig. 8) indicates considerably lower winter temperatures during the period $45-15 \mathrm{ka}$ BP as compared to the Holocene (Siegert et al., 1999). Similar results have been obtained from ice wedges at the Bykovsky Peninsula and from the nearby Bol'shoy Lyakhovsky Island (Fig. 5, Meyer et al., 2002a, b). The isotope studies suggest that the winter conditions had not changed radically from around $40 \mathrm{ka} \mathrm{BP}$ until the Bølling/Allerød warming events.

Pollen spectra from the LGM have been analysed from several sites in the western Putorana Plateau (Hahne and Melles, 1997, 1999), in the Labaz Lake area (Andreev et al., 2002a), at Lake Levinson-Lessing in the

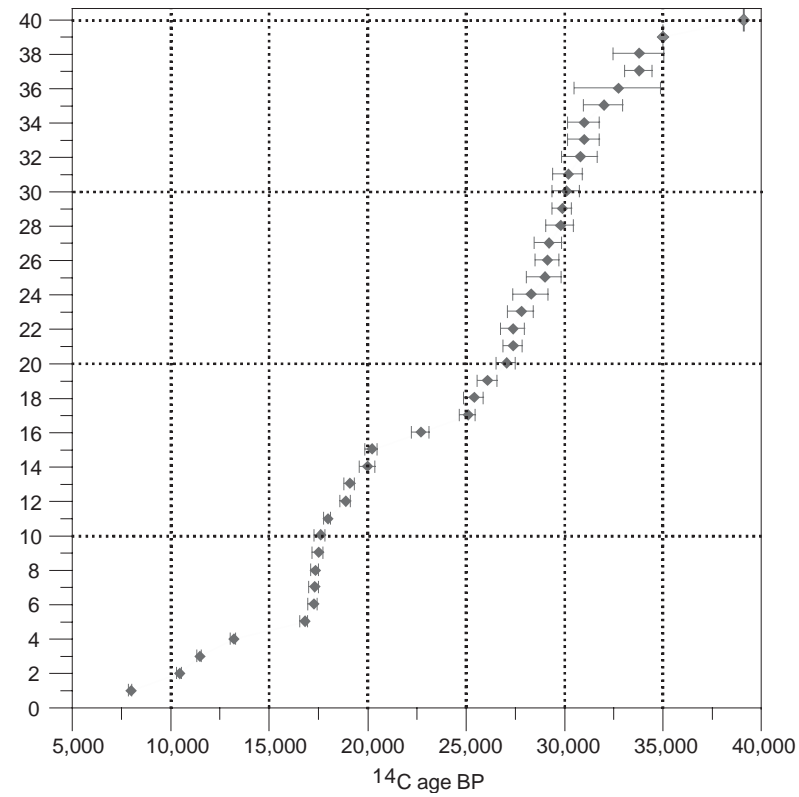

Fig. 7. AMS ${ }^{14} \mathrm{C}$ dates on "Cape Sabler-type" sediments from five localities within the Taymyr Lake basin (Cape Sabler, Upper Taymyra River delta, Baskura Peninsula, Fedorov Island, and Ovrazhny Peninsula), sorted according to age (data from Möller et al., 1999 and unpublished data from Möller). Except for Cape Sabler, the dates are from top and bottom of the sections. Date nos. 39 and 40 are infinite ages from lowermost samples at Cape Sabler and Ovrazhny Peninsula, respectively.

Byrranga Mountains (Hahne and Melles, 1999). The Late Weichselian pollen spectra are similar to Late Pleistocene pollen spectra. Also the pollen spectrum obtained from Cape Sabler (SAO-1 section) (Fig. 9, Andreev et al., 2003) shows some of the characteristics of LGM pollen spectra of the Taymyr Peninsula.

Low pollen concentrations and large amounts of reworked pre-Quaternary pollen are typical for all LGM deposits. Pollen of plants typical for disturbed soils, like Chenopodiaceae and Asteraceae, are also common. It is inferred that barren slopes, dry lake beds and cryogenic patterned ground favoured deflation and other processes of soil erosion. The low pollen concentration in the LGM sediments can be explained by both discontinuous vegetation cover and low pollen productivity, caused by the unfavourable climatic conditions.

In general, pollen data suggest that open steppe-like plant communities with Artemisia, Poaceae, and Asteraceae dominated the vegetation in the eastern and central parts of the North Siberian Lowland, between the Byrranga Mountains in the north and the Putorana Plateau in the south. Tundra-like communities with Betula nana, Salix polaris, Dryas, Saxifraga, Oxyria, Carex and some Brassicaceae were common in more mesic sites. The rare tree and shrub pollen are mostly reworked from older sediments. Exposed tills in the study area might be one source for this material. 

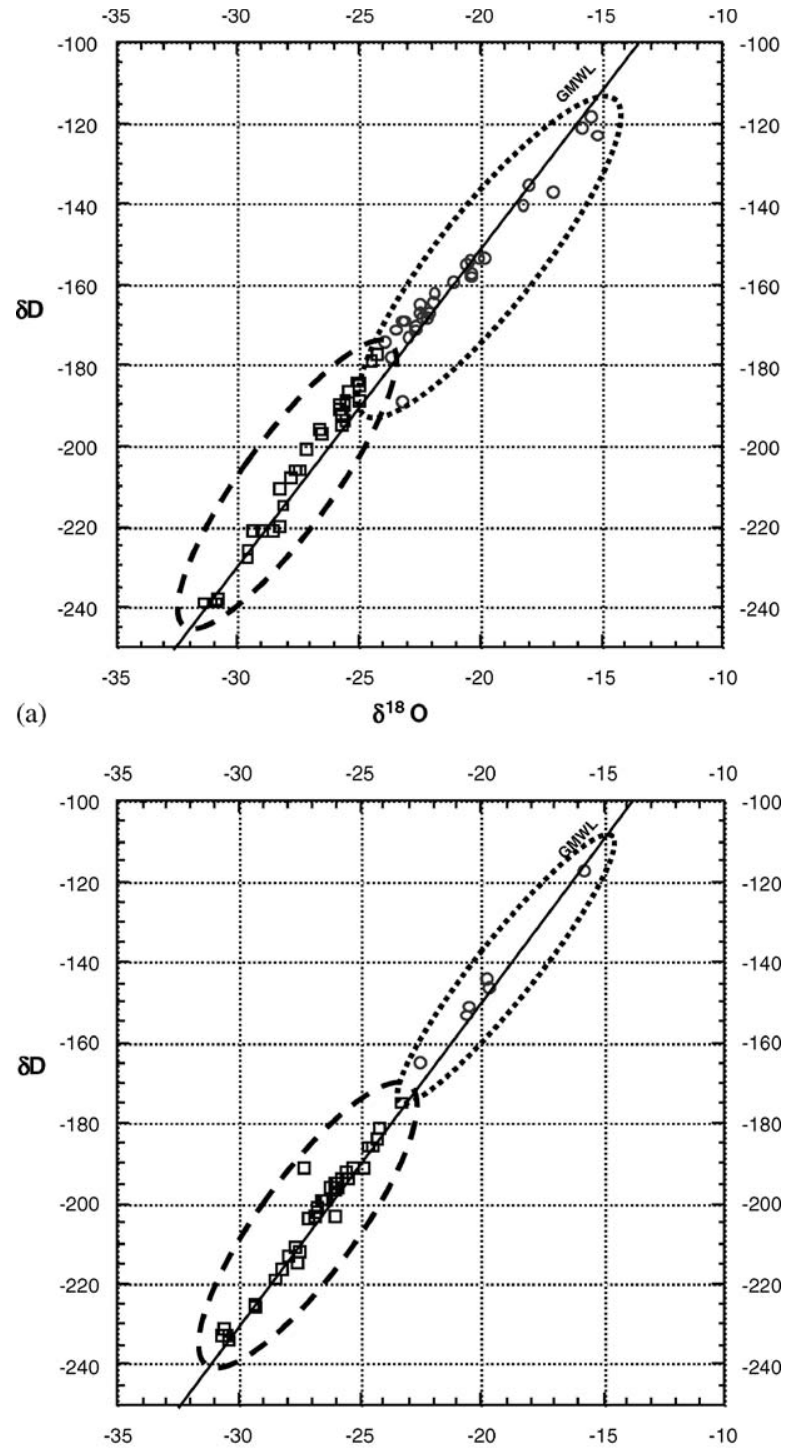

(b)

$$
\delta^{18} \mathrm{O}
$$

Fig. 8. Stable-isotope composition of ice wedges on the Taymyr Peninsula formed during Late Pleistocene (squares) and Holocene (dots): (a) SAO-1 section, Cape Sabler; (b) northern shore zone of the Labaz Lake (after Dereviagin et al., 1999; Siegert et al., 1999).

Based on palynological records from Levinson-Lessing Lake and Cape Sabler, Andreev et al. (2003) used the best modern analogue and information-statistical methods to reconstruct the LGM climate for the area. They conclude that temperatures at ca $18 \mathrm{ka}$ BP were up to $5^{\circ} \mathrm{C}$ colder than today and annual precipitation was ca $100 \mathrm{~mm}$ lower.

Results of plant-macrofossil analysis of samples from the Cape Sabler section (Fig. 10, Kienast et al., 2001) correlate well with the pollen data from the same sequence (Fig. 9). The recorded flora in three horizons from the SAO-1 section at Cape Sabler that are radiocarbon dated to 30,27 , and $18 \mathrm{ka} \mathrm{BP}$ reflect a herbaceous tundra-steppe environment. At all three levels the floristic composition is characterized by a high species diversity dominated by xerocryophilous taxa (Fig. 10). These include Papaver sect. scapiflora, Dryas punctata, Brassicaceae, Saxifraga, Potentilla and Asteraceae. Hydrophytes and marsh plants were not recorded in the horizons formed during the LGM at about $18 \mathrm{ka}$ BP. The relative abundance of the mountain-steppe plant Orostachys spinosa (Crassulaceae) is consistent with these associations and an important indicator of severe cold and arid conditions during the deposition of the beds. Today this species only grows in distinct rainshadow areas of the East Asian mountains, in relict tundra-steppe communities of NE Yakutia and in steppe areas of central Yakutia (Yurtsev, 1981). The predominance of pioneer plants is typical for young succession stages and is also an important feature of the macrofossil spectra. Thus, severe continental climatic conditions are indicated both by the plant-macrofossil and pollen records from the studied permafrost sequences of the Taymyr Peninsula. Palaeobotanical records and isotope data from ground ice (cf. Siegert et al., 1999) indicate that a warmer interstadial period existed at $14-11 \mathrm{ka} \mathrm{BP}$.

\subsubsection{Severnaya Zemlya}

Information on the palaeoclimate here has been obtained from sediment cores recovered from Lake Changeable on October Revolution Island (Locality 4, Fig. 1). These cores were investigated with a multidisciplinary approach that covered sedimentological, biogeochemical, mineralogical, and palaeoecological methods. The results allowed the reconstruction of facies successions that describe the development of the lake and the associated climatic history (Raab, 2000; Raab et al., 2003).

Age control of the sedimentary sequence was obtained using a series of ${ }^{14} \mathrm{C}$-AMS dates on Foraminifera, humic acid extracts, and remains of insects and plants. As these results did not show a consistent age sequence, two IRSL dating on quartz in the sand fraction and six optically stimulated luminescence (OSL) dating on feldspar in the fine silt fraction were used in order to provide a better age control (Fig. 11). Following a glaciation during the Early Weichselian or early Middle Weichselian, a presumably short marine phase immediately after deglaciation, and a drying of the Changeable Lake depression prior to $33 \mathrm{ka}$ BP the climate before the Late Weichselian glaciation was characterized by warmer and wetter conditions. Due to higher precipitation and meltwater production, sedimentation in the lake basin started at about $33 \mathrm{ka} \mathrm{BP}$ and continued until $23 \mathrm{ka}$ BP. No vegetation information could be obtained from the lake sediments due to lack of pollen.

However, considering that mammoths were present on Severnaya Zemlya around 25, 20, and $19 \mathrm{ka}$ BP the area must have been vegetated (Bolshiyanov and 


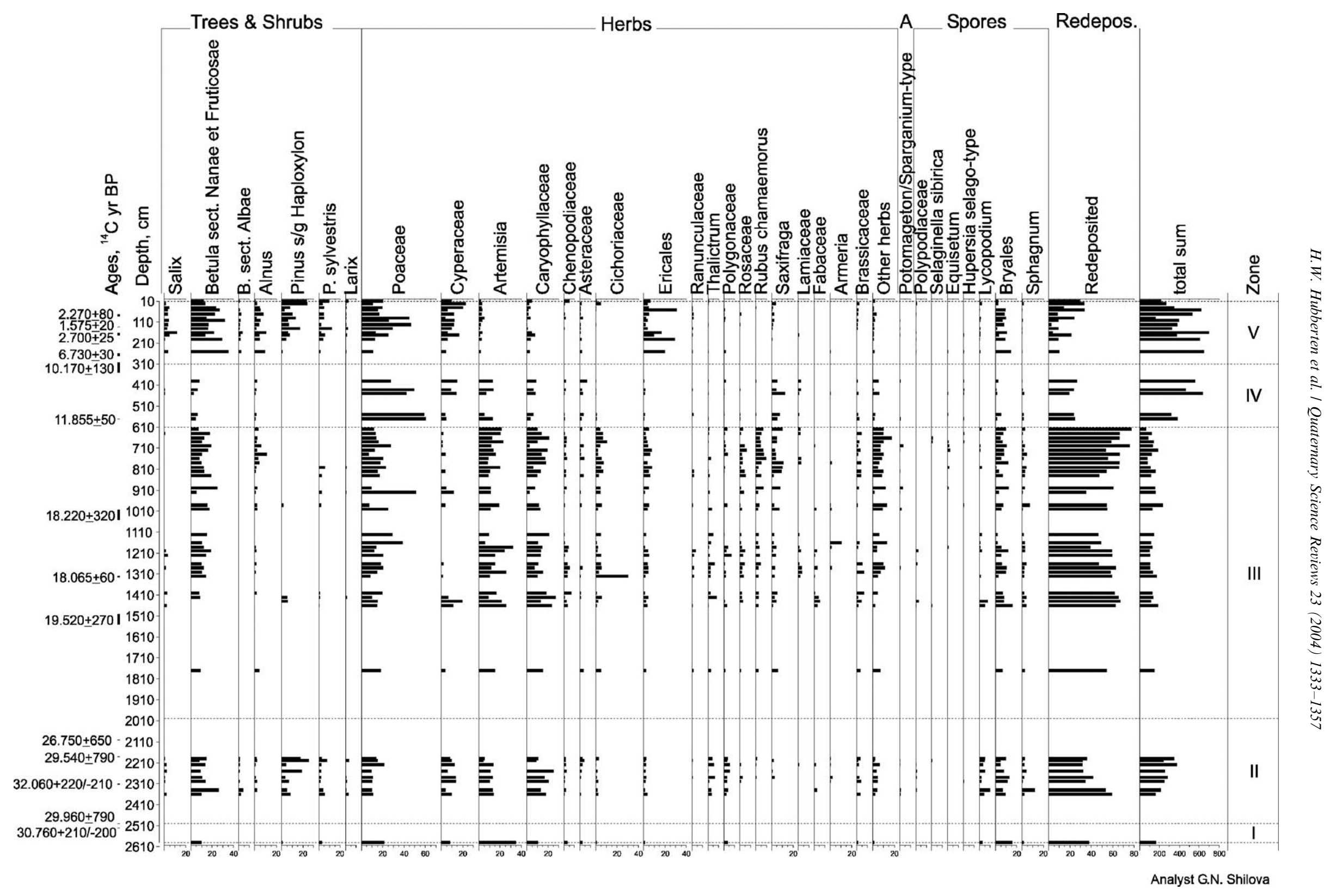

Fig. 9. Pollen diagram of the SAO-1 section at Cape Sabler, Taymyr Lake (Andreev et al., 2003). 
Makeyev, 1995). Judging from other pollen records from islands east of Severnaya Zemlya (Makeyev et al., 1993; Andreev et al., 2001) it seems likely that the area was at least partly covered by tundra-steppe vegetation.

At about $22 \mathrm{ka}$ BP, a change to colder and drier climate seems to have occurred. The formation of evaporitic sediments on the lake floor and a very low accumulation rate suggests that a perennial ice cover formed on the lake and that it received very little water. Very low precipitation is needed to maintain the small

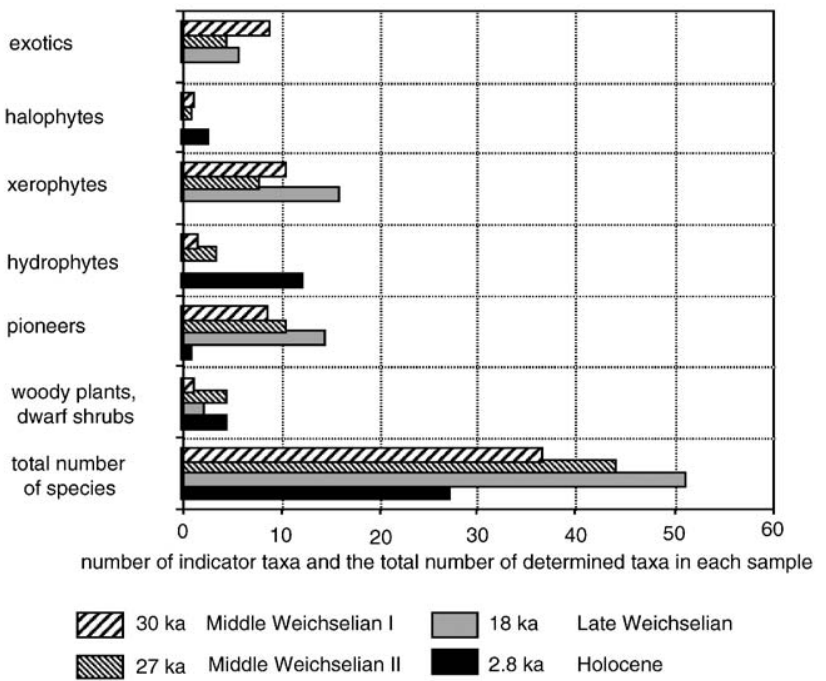

Fig. 10. Distribution of ecological plant groups in the sediments of section SAO-1 at Cape Sabler (Kienast et al., 2001). local ice caps in the archipelago (Makeyev and Bolshiyanov, 1986).

The climatic change that occurred at the termination of the Pleistocene is documented in this lake by the beginning of sedimentation under freshwater conditions some time between 19 and $12 \mathrm{ka} \mathrm{BP}$. The climate changed to more humid and warmer conditions from that time leading to a much higher sedimentation rate in Changeable Lake.

\subsubsection{West Siberian Plain}

The 'maximalist model' of a large Late Weichselian ice sheet coupled with a huge ice-dammed lake in West Siberia suggested by Volkov et al. (1978) and further elaborated by Grosswald and Hughes (2002) is in total discrepancy with the QUEEN data from adjacent areas (Svendsen et al., 1999; Mangerud et al., 2002). The 'minimalist' mountain ice sheets by Biryukov et al. (1988) are also refuted by our investigations in the Urals and in Central Siberia. Numerous bodies of fossil glacier ice preserved close to the surface proved to be older than the range of the radiocarbon method (Astakhov and Isayeva, 1988). The present syngenetic ice wedges have been growing without interruption for the last $37 \mathrm{ka}$ (Vasilchuk, 1992; Vasilchuk and Vasilchuk, 1998). Also remains of Late Weichselian mammoth fauna are known from West Siberia (Astakhov, 1998). In the lowest central part of the plain no deep-water lacustrine sediments are found within the Late Weichselian radiocarbon bracket (Astakhov, 1989). Therefore here we can only describe Late Weichselian environments of the

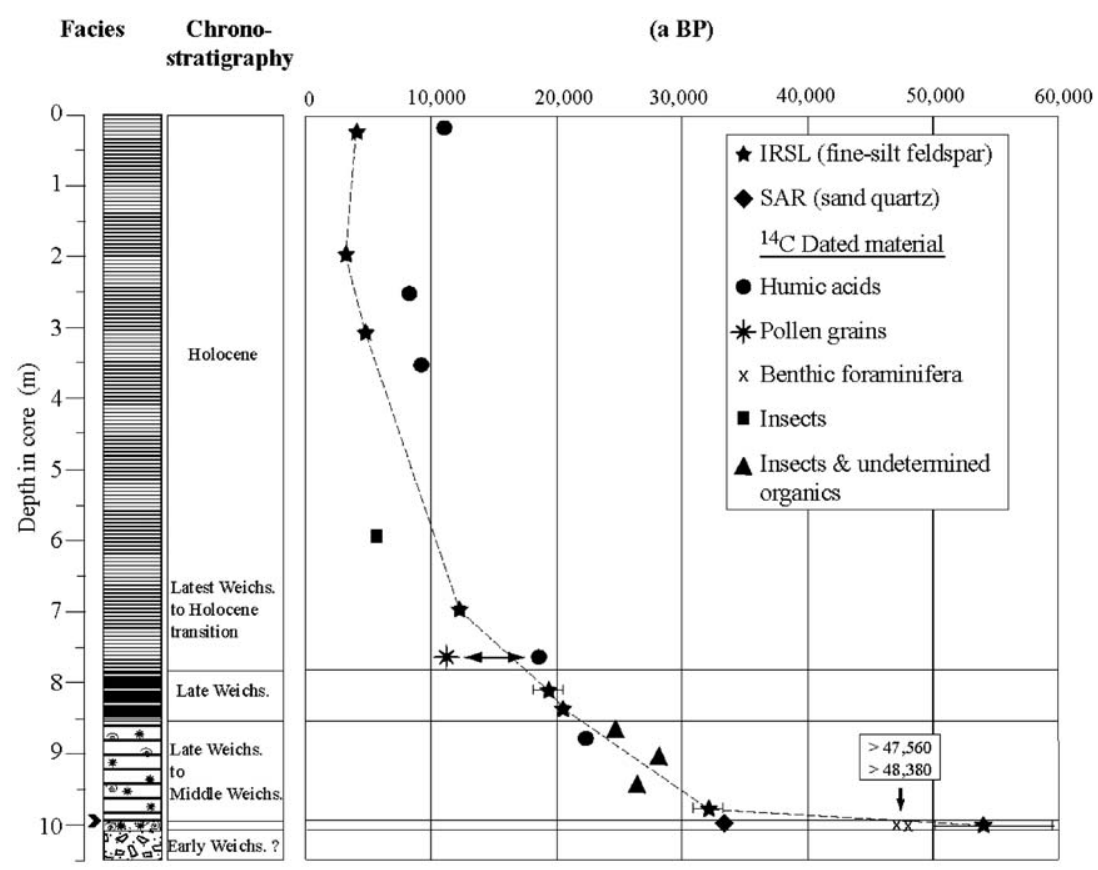

Fig. 11. Radiocarbon and IRSL ages from the sedimentary sequence of Changeable Lake, Severnaya Zemlya (after Raab, 2000; Raab et al., 2003). 
West Siberian Plain without glacial ice or ice-dammed lakes, according to the most reliable geological data from Russian sources, partly discussed before in Astakhov (1992).

In West Siberia (Locality 5, Fig. 1) the climate during the final stage of the Middle Weichselian appears to have been relatively mild, although not of interglacial type. This interval is often recognized from the occurrence of palaeosols in the south and thin seams of mossy peat in the Arctic. Pollen spectra with dominance of arboreal taxa are recorded from many alluvial sequences of this period in the southern part of the West Siberian Plain. Diagrams from alluvial sequences from the areas along the middle course of the Yenisei, radiocarbon dated to $30-24 \mathrm{ka} \mathrm{BP}$, are characterized by high percentages of Picea with an admixture of Larix, in contrast to the present-day spectra, which reflect the southern taiga subzone dominated by Pinus sibirica. This difference along with the higher percentage of xerophytic herbs in the Middle Weichselian sediments suggest a more continental climate compared to the modern one. From the Lipovka section $\left(58^{\circ} \mathrm{N}, 67^{\circ} \mathrm{E}\right)$ on the Tobol river in the southwestern part of the West Siberia Plain in situ stumps of larch trees from a peat layer, capped by $12 \mathrm{~m}$ of loess-like silts, have been radiocarbon dated to around 30-31 ka BP (Kaplyanskaya and Tarnogradsky, 1974; Kind, 1974; Arkhipov et al., 1980). Palaeosol analyses, mollusc evidence, pollen and plant macrofossils reflect a forest-tundra environment at this time, in contrast to the southern taiga of the present. The occurrence of large syngenetic ice-wedge casts a $1000 \mathrm{~km}$ to the south of their present distribution suggests much colder winters at the end of the Middle Weichselian than today.

In the central and southern parts of the West Siberian Plain the late Middle Weichselian interstadial horizon is usually covered by a continuous loess mantle (Volkov, 1971). In the Arctic it is replaced by a discontinuous cover of the perennially frozen Yedoma silt (Bolikhovsky, 1987), which in our opinion is also basically of aeolian origin. The lower part of this formation is often recognized by bluish and greenish colours, reflecting a reducing environment. This part of the subaerial formation is sometimes referred to as 'wet loess' (Astakhov, 1989) and is believed to reflect tundra conditions with numerous ponds. The 'wet loess' and contemporaneous waterlain sediments are in places covered by thin organic layers that have been radiocarbon dated to 23-20 ka BP (Vasilchuk, 1992; Krivonogov et al., 1993). In the area around Novosibirsk, a palaeosol dated to $26-24 \mathrm{ka} \mathrm{BP}$ is believed to reflect a steppe environment with parklands, not much different from the present (Volkov and Zykina, 1984). This soil was rewashed in a presumably much colder and wetter climate with permafrost at around 21-20 ka BP.
Extremely low winter temperatures for the LGM time are inferred from the occurrence of ice-wedge casts south to $52^{\circ} \mathrm{N}$. A very continental climate is also indicated by a layer of relict permafrost under $100-150 \mathrm{~m}$ of thawed rock. This layer extents southwards to the 59th parallel which is $800 \mathrm{~km}$ south of the present climatic limit of permafrost formation (Baulin et al., 1981). In the Arctic old permafrost contains thick stratiform bodies of fossil glacier ice preserved from the Early Weichselian ice advances (Astakhov and Isayeva, 1988).

The spatial pattern of the aeolian formation reflects predominant wind directions from the west and north in the central part of the West Siberian Plain (Astakhov, 1992) and from WSW in the southern part of the Plain (Volkov, 1971). The fact that loess sheets and sand dunes reach below the present water level along the large Siberian rivers gives evidence of only limited fluvial activity at this time (Astakhov, 1989). The scarce pollen grains from this formation belong to xerophytic herbaceous communities (Artemisia, Ephedra, and Chenopodiaceae) with some dwarf shrubs, indicating 8$10^{\circ} \mathrm{C}$ lower annual temperatures than at present (Arkhipov et al., 1980). Humidification seems to have occurred around 15-14 ka BP, when organic and waterlaid sediments started to accumulate again (Kind, 1974; Arkhipov et al., 1980; Volkov and Zykina, 1984).

On the eastern Yamal Peninsula there is an important and well-studied section named Syo-Yakha (Fig. 12). This section displays more than $20 \mathrm{~m}$ of Yedoma-like silt with thin moss-mat layers. Altogether 15 radiocarbon dates (AMS and conventional dating) with ages ranging from 37 to $17 \mathrm{ka} \mathrm{BP}$ in the correct stratigraphic order have been obtained from this section (Vasilchuk and Vasilchuk, 1998; Vasilchuk et al., 2000a, b). Pollen and spores from this section suggest that a humid episode may have occurred around 22-21 ka BP. Nearly similar results were obtained from the Mongotalyang section $\left(72^{\circ} \mathrm{N} / 75^{\circ} \mathrm{E}\right)$; (Vasilchuk, 1992). The section is pierced by two generations of thick (syngenetic) ice wedges, which grew simultaneously with sediment accretion. Radiocarbon dates of plant remains from the ice in the wedges yielded ages in the range $21-14 \mathrm{ka} \mathrm{BP}$, indicating that the large ice wedges date from the LGM period. Measured oxygen-isotope values are about $-23 \%$ (Fig. 12 ), as compared to $-17 \%$ for Holocene wedge ice in this area. Vasilchuk et al. (2000a) interpreted this difference to indicate that winter temperatures during ice-wedge formation were $6-9^{\circ} \mathrm{C}$ lower than today. Ice wedges $14-11 \mathrm{ka} \mathrm{BP}$ old on the Gydan Peninsula, $71^{\circ} \mathrm{N} /$ $78^{\circ} \mathrm{E}$, yielded $\partial^{18} \mathrm{O}$ values from $-22.6 \%$ to $-19.9 \%$, suggesting milder winters, but still $3-5^{\circ} \mathrm{C}$ colder than the present ones (Vasilchuk, 1992).

A nearly similar development has been recorded in the large Marresale section on western Yamal (Forman et al., 1999). The very cold winters dominating in the Arctic since at least ca $40 \mathrm{ka}$ BP agree with ice-wedge 


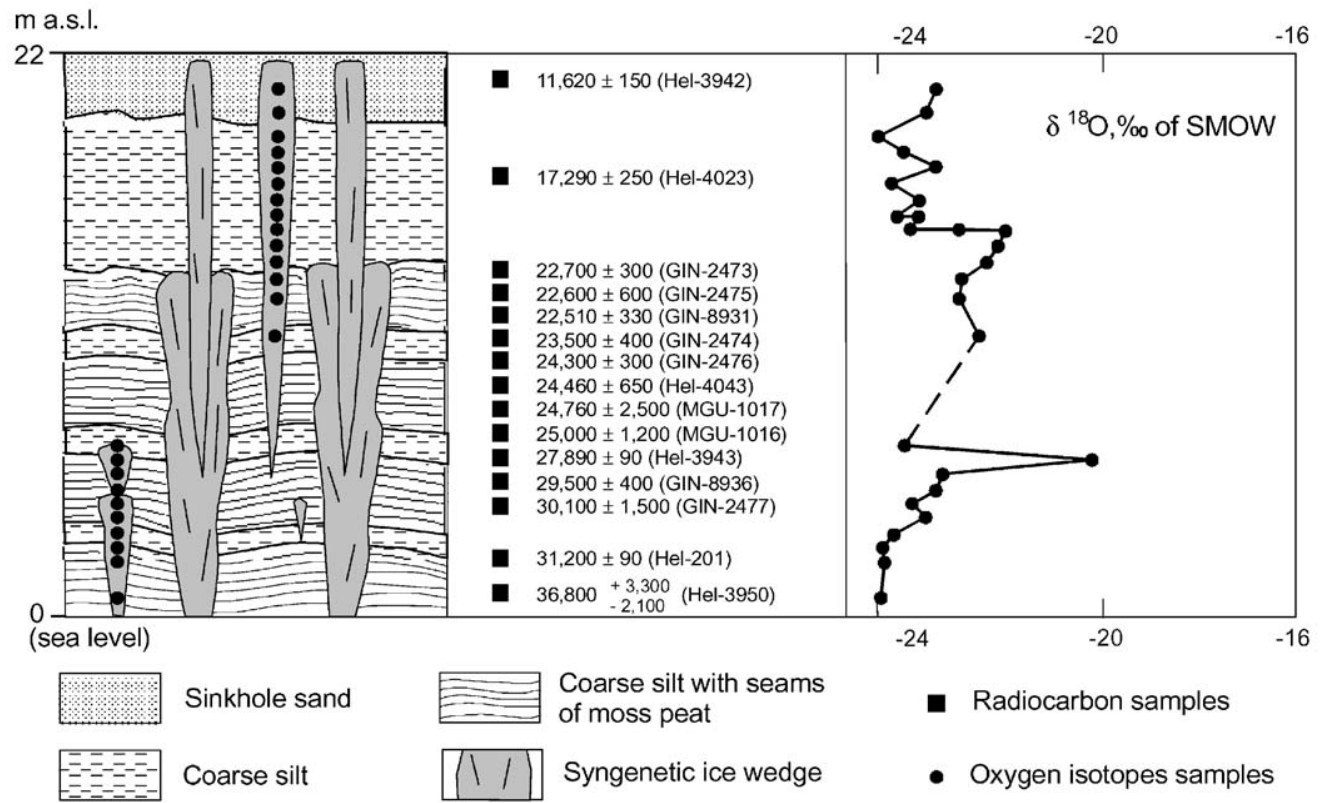

Fig. 12. Sediment stratigraphy at the coastal section of Syo-Yaka, eastern Yamal, West Siberia. From Mangerud et al. (2002), simplified from Vasilchuk et al. (2000b).

growth in the southwest of the West Siberian Plain (Kaplyanskaya and Tarnogradsky, 1974).

A review of the available evidence indicates the following development in West Siberia: (1) relatively humid but still continental environments with solid permafrost prevailed at the end of the Middle Weichselian around 37-30 ka; (2) a warmer continental climate of interstadial type is registered for the time span 30-24 ka BP; (3) this was replaced by a progressive cooling with widespread permafrost in a relatively humid environment between 24 and $20 \mathrm{ka}$ BP; (4) the latter changed into a very cold and arid phase after ca $20 \mathrm{ka} \mathrm{BP}$; and (5) the late-glacial humidification in basically permafrost environments started ca $15 \mathrm{ka} \mathrm{BP}$.

\subsubsection{Polar Ural}

The distribution and size of local glaciers in the Urals (Locality 6, Fig. 1) may also provide information about the climatic conditions during the LGM. Presently, only a few small cirque glaciers exist in the mountains (Grosswald and Kotlyakov, 1969). Our geological field investigations have revealed that no major ice caps have formed in the Urals since the last interglacial (Dolvik et al., 2002). The most extensive glaciation occurred during the Early Weichselian, when a piedmont glacier on the western side of the Polar Urals coalesced with an ice lobe from the Barents-Kara Sea Ice Sheet (Astakhov et al., 1999). We have observed some end moraines near the front of the present-day cirque glaciers and in the high altitude valleys that possibly outline extended valley glaciers during the LGM, but they have not been dated. From available evidence we conclude that the equilibrium-line altitude (ELA) depression during the LGM was a maximum of $300 \mathrm{~m}$ compared to the present, and possibly the glaciers were not much larger than today (Dolvik et al., 2002). Considering that climate during the LGM was much colder than today, the limited ice growth in the Ural Mountains suggests a much drier climate there, with minimal winter accumulation. This is in good agreement with the data from the Pechora Lowland, where only aeolian formations represent the LGM time (Astakhov et al., 1999; Mangerud et al., 1999).

\subsubsection{Pechora Lowland}

Contrary to the previous conclusions (Arslanov et al., 1987) no signs of glacial activity have been encountered in the Pechora Basin within the range of radiocarbon method, although ancient permafrost features are widespread (Astakhov et al., 1999; Mangerud et al., 1999, 2002). The only deposit of buried glacier ice found west of the Urals was fossilized more than $45 \mathrm{ka}$ ago (Astakhov and Svendsen, 2002). The margin of the Barents-Kara Ice Sheet during the LGM was situated well offshore (Gataullin et al., 2001; Svendsen et al., 2004a, b). Analyses of collected bones, mainly from archaeological sites (Pymva-Shor, Byzovaya, and Mamontovaya Kurya) reflect a relative rich faunal composition in the Pechora Lowland (Locality 7, Fig. 1) during the later part of the Middle Weichselian (Mangerud et al., 1999, 2002; Pavlov et al., 2001; Svendsen and Pavlov, 2004). From the Palaeolithic site Byzovaya (29-28 ka BP) there is evidence for the presence of mammoths, woolly rhinoceros (Coelodonta antiquitatis), 
muskox (Ovibos moschatus), bison, bear (Ursus sp.), horse, reindeer (Rangifer tarandus), hare (Lepus sp.), polar fox (Alopex sp.), and various rodents (Pavlov and Indrelid, 2000). The fact that humans were present in the area during this interval is also an indication that the landscape sustained herds of herbivorous animals; especially mammoths seem to have been an important prey animal. Pollen from the silt sequence at the Palaeolithic site Mamontovaya Kurya reflect a tundrasteppe environment with some willow scrub along the river at around $32-30 \mathrm{ka} \mathrm{BP}$ (Halvorsen, 2000). At the transition (25-24 ka) to the Late Weichselian the scrub elements disappeared and the local vegetation became dominated by Artemisia and Poaceae, resembling a cold steppe environment.

Alluvial deposits from the Middle-Late Weichselian transition recognized at several locations in the Pechora Basin form the second terrace along the rivers (Fig. 13). At Mamontovaya Kurya a thick sequence of crossbedded sediments indicate that the river Usa was of the same size as today during the period $27-24 \mathrm{ka}$ BP (Pavlov et al., 2001). Along the Kolva river, a tributary to Usa, similar alluvial formations with remains of a mammoth fauna of nearly the same age have been found (Mangerud et al., 1999, 2002). This would imply that the generally treeless tundra-steppe landscape was humid enough to support fairly fertile river valleys with almost normal water discharge. Such riverine environments that sustained a rich fauna were the natural pathways for northbound human migrations during mild interludes.

During the Late Weichselian the periglacial environment in the Pechora Basin was characterized by a much wider permafrost distribution than today (Astakhov et al., 1999). The present-day discontinuous permafrost is not more than $100 \mathrm{~m}$ thick in the area to the west of the Pechora River. In contrast, Pleistocene permafrost has survived as a deeply buried relict layer in the boreal forest zone down to $64^{\circ} 30^{\prime} \mathrm{N}$ and as a solid surficial permafrost that is $300-400 \mathrm{~m}$ thick in the eastern tundra

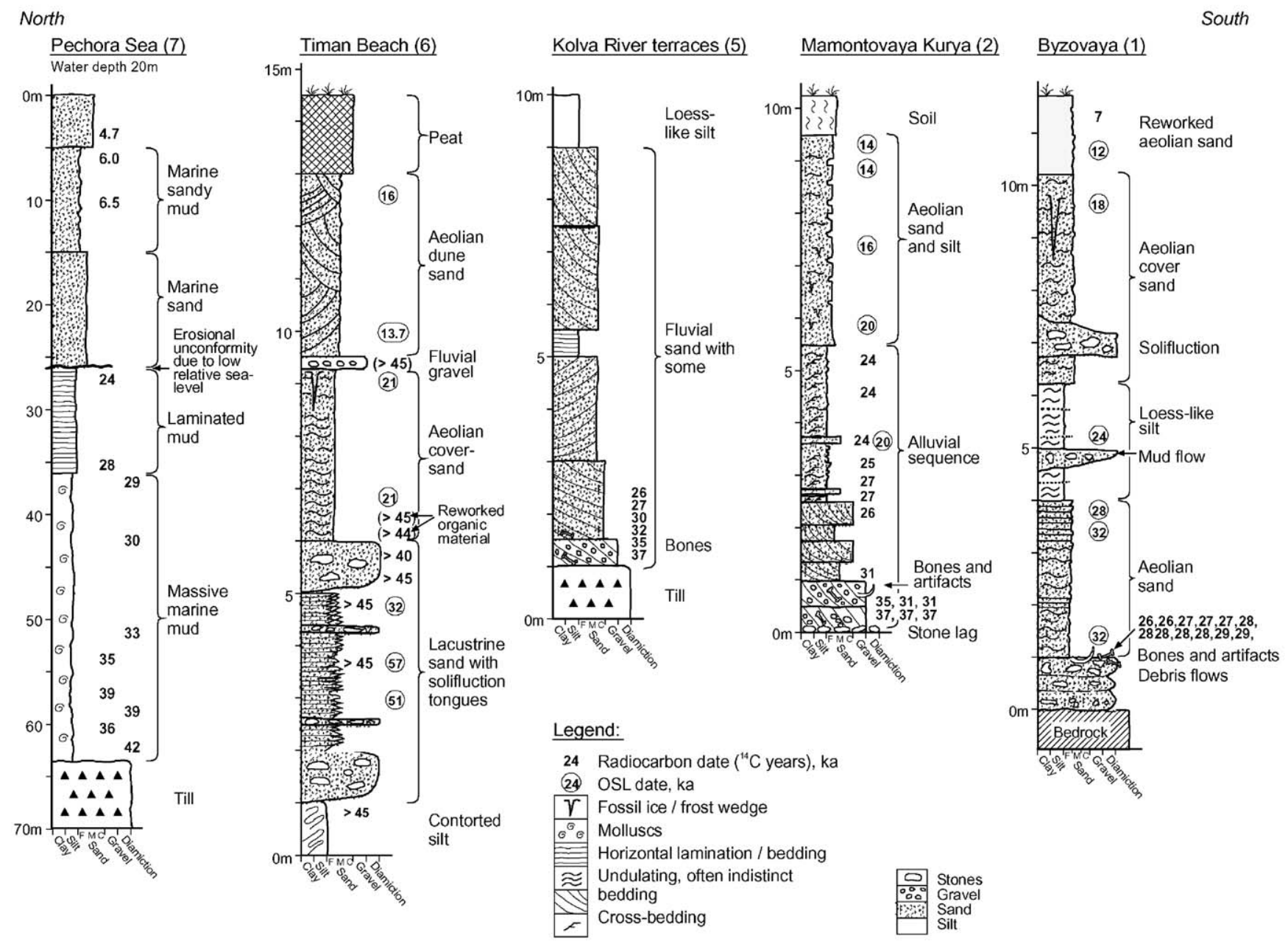

Fig. 13. A selection of sediment logs from key sites plotted in an N-S profile from the Pechora Sea to the southern Pechora Lowland. The Middle to Late Weichselian stratigraphy reveals alluvial and aeolian deposits covering strata of bones and artefacts at the Palaeolithic sites Mamontovaya Kurya and Byzovaya and bone layer at Kolva river terraces. From Mangerud et al. (2002). 
(Yershov, 1988). Perhaps the best manifestation of a former thicker and colder permafrost is the widespread occurrence of relict ice-wedge polygons (Astakhov et al., 1999), which are typically from $10-15$ to $300-400 \mathrm{~m}$ across (Popov, 1962). In the present-day climate only smaller ice wedges can grow along the Barents Sea coast. Radiocarbon dates from organic infills in some large icewedge casts suggest that the thick Pleistocene permafrost started to melt prior to $12 \mathrm{ka} \mathrm{BP}$ (Mangerud et al., 1999). Thick sand and silt formations with shrub remains started to accumulate ca $13 \mathrm{ka}$ in large, subsequently drained, thaw lakes (Astakhov and Svendsen, 2002). Sediment coring confirms that many present lakes that characterize the hummock-and-lake glaciokarst landscape to the north of the Early Weichselian ice sheet limit were formed as a result of permafrost melting that seems to have started around $13 \mathrm{ka}$ BP, i.e. well after the LGM (Henriksen et al., 2003).

The investigations in the Pechora Basin reveal a widespread occurrence of aeolian surface deposits characterized by a vague and discontinuous lamination draping the underlying topography (Astakhov et al., 1999; Mangerud et al., 1999, 2002). OSL dates disclose that much of the aeolian sediments accumulated during the period 27-10 ka BP (Astakhov et al., 1999; Mangerud et al., 1999, 2002). At the Palaeolithic sites Mamontovaya Kurya and Byzovaya, which have been radiocarbon dated to around 36 and $28 \mathrm{ka} \mathrm{BP}$, respectively (Pavlov et al., 2001), the strata with bones and artefacts are covered by up to $10 \mathrm{~m}$ of aeolian sand that mostly accumulated during the Late Weichselian. Similar aeolian sediments have also been studied near the Barents Sea coast (Astakhov and Svendsen, 2002) and are recognized in most areas of the Pechora Basin. In western Europe similar sediments described as "coversands" were frequently deposited south of the Scandinavian Ice Sheet during the Late Weichselian. This type of sediment reflects a considerably drier and windier climate than during the Middle Weichselian and Holocene periods. However, in most cases the dated sequences with aeolian cover sand have turned out to be somewhat younger than $20 \mathrm{ka}$ BP. Some observations suggest that solifluction, rather than deposition of aeolian sediments, was a common process during the LGM. The stratigraphy at Byzovaya may suggest that the general cold and dry period during the Late Weichselian was punctuated by more humid events with low-energy temporary streams (Fig. 13).

It is noteworthy that we have only found one single bone that has been radiocarbon dated to the period around LGM (21-18 ka BP), and this find belongs to the unique locality Pymva-Shor with the warmest groundwater spring in the Russian Arctic (Mangerud et al., 1999). It seems reasonable to assume that the general lack of bone finds from this interval reflects a decrease in the vegetation cover.
Sediment coring of a lake basin in the northern part of Timan Ridge has produced a long Late Weichselian and Holocene pollen record (Paus et al., 2003). The oldest part of this sequence, which has been radiocarbon dated to around $20 \mathrm{ka} \mathrm{BP}$, reflects a treeless herbaceous vegetation. However, the lowermost radiocarbon date from this lacustrine sequence is considered uncertain and Paus et al. (2003) therefore conclude that the lake formed as a result of a climatic warming just after the LGM.

Considering that there seems to be no fluvial terraces from the period between 24 and $13 \mathrm{ka}$ we believe the river discharge dropped volumetrically during the LGM. Most of the fluvial terraces except the Holocene floodplain are mantled with aeolian sediments from the LGM. However, it is possible that alluvial sediments from this time rest below the present river bed and thus might be potentially identified in boreholes.

Based on the available evidence the following development can be outlined for this region: The climatic conditions were relatively mild and humid during the later part of the Middle Weichselian, up to about 27,000 ${ }^{14} \mathrm{C}$ years BP. A change to a much drier and colder climate occurred at the transition to the Late Weichselian, as shown by the widespread accumulation of aeolian sediments. During the LGM the southern limit of the permafrost was located far to the south of the Pechora Basin reflecting a much colder climate than today. However, it should be noted that very few sediment sequences covering this period (21-18 ka) have been found on the Pechora Lowland and the environmental conditions are therefore poorly constrained. A pronounced warming started around $13 \mathrm{ka}$ when much of the permafrost melted, forming the numerous lakes that characterize the present-day landscape in the Arctic.

\subsubsection{The northwestern Russian Plain}

In the valleys of Severnaya Dvina and Vaga rivers south of Arkhangelsk (Locality 8, Fig. 1), marginal moraines from the Scandinavian Ice Sheet were deposited during the Late Weichselian. The maximum position was attained some $17 \mathrm{ka}$ BP ago, and deglaciation started close to $15 \mathrm{ka}$ BP ago (Larsen et al., 1999). The Scandinavian Ice Sheet seems not to have reached the area of the Pyoza River, a tributary to the Mezen River northeast of Arkhangelsk (Houmark-Nielsen et al., 2001; Lyså et al., 2001).

The environmental changes from Middle to Late Weichselian in the area are illustrated in Fig. 14. The Middle Weichselian sediments were deposited in a fluvial environment from about $66 \mathrm{ka}$ until the advance of the Late Weichselian glacier (dates in Fig. 14). A peat horizon found in the lower part of the Middle Weichselian unit at the Pasva section (located on the Vaga River) suggests taiga vegetation and a flora 


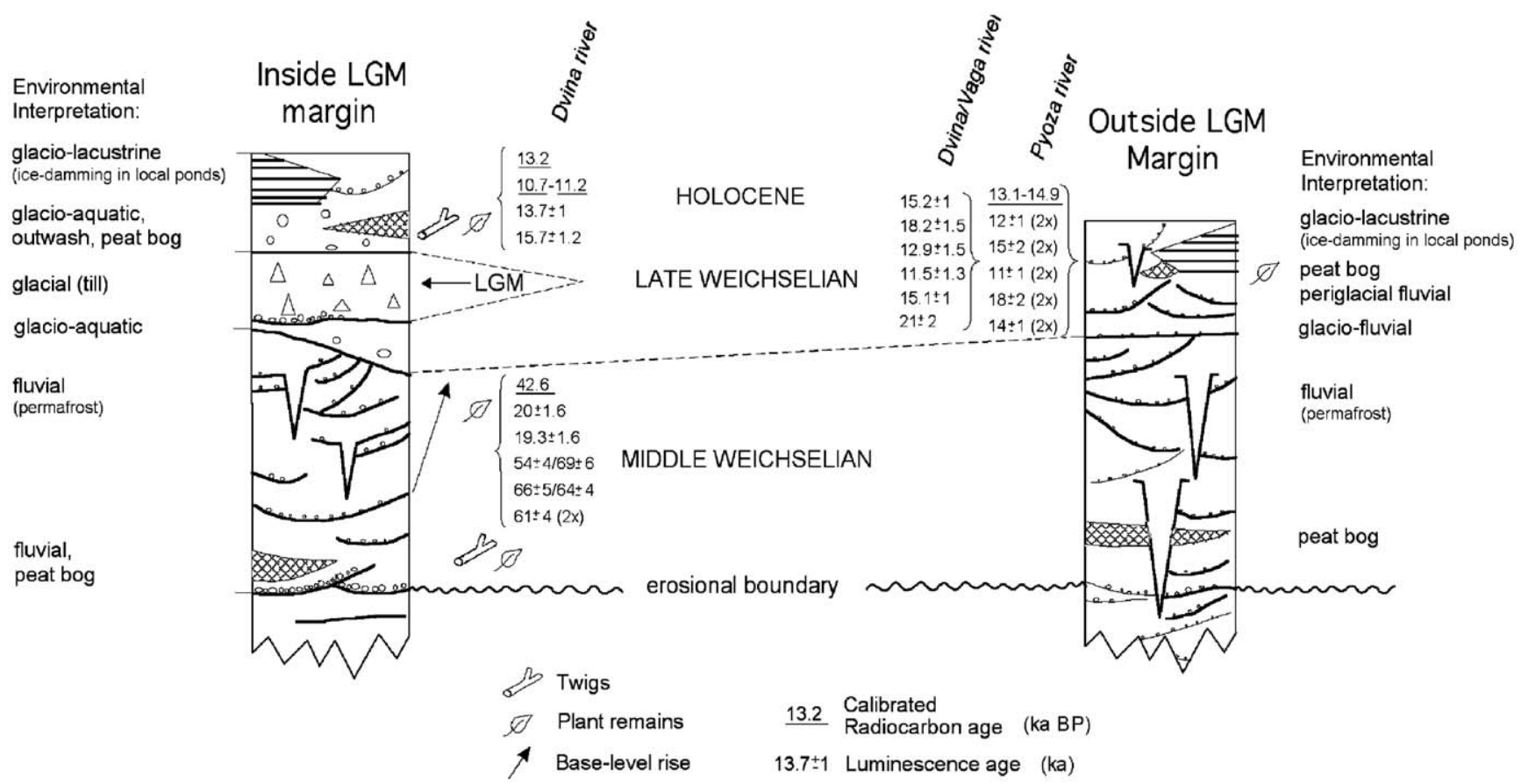

Fig. 14. Composite Middle Weichselian to Holocene stratigraphy from inside and outside the LGM limit in the Arkhangelsk area. All dates are from Lyså et al. (2001) (Dvina and Vaga rivers) and Houmark-Nielsen et al. (2001) (Pyoza River).

indicative of permafrost development (Devyatova, 1982). Towards the top of this unit, at several sites along rivers Severnaya Dvina and Vaga and above the peat horizon at Pasva, incipient frost cracks and syngenetic ice-wedge pseudomorphs are observable.

At one locality inside the LGM limit (Smotrakovka section, Lyså et al., 2001) is a unit of large-scale inclined and trough-cross-bedded fluvial sand more than $23 \mathrm{~m}$ thick. The fluvial sediments were probably deposited during a continuous rise of base level. As the top of this succession yielded luminescence ages of 19.3 and $20 \mathrm{ka}$, the rise in base level was probably caused by isostatic subsidence due to growth and advance of the Late Weichselian ice sheet.

A northwards drainage pattern prevailed throughout the entire Middle and Late Weichselian period. Glaciolacustrine sedimentation during the LGM occurred in small ponds along the ice limit. As the Scandinavian Ice Sheet advanced into the area from the northeast, main rivers Dvina and Vaga were ice-dammed, and glaciofluvial drainage was forced northwards along the ice margin and into the Barents/Kara Sea.

In the Pyoza area, glaciolacustrine deposition in proglacial lakes caused by ice from the Barents-Kara Sea continued until about 60 ka (Houmark-Nielsen et al., 2001). After a period of erosion and glacio-isostatic uplift under subaerial conditions, wide periglacial floodplains of rivers draining westwards appeared in the Late Weichselian. Plant remains and peat sporadically occur in muddy depression fillings, which are often strongly cryoturbated. The plant remains indicate vegetation dominated by Dryas octopetala, S. polaris, and terrestrial mosses. The gravelly and sandy fluvial sediments are characterized by galleries of frost- and ice-wedge pseudomorphs, confirming the periglacial conditions inferred from the vegetation. The periglacial sediments are dated to the Late Weichselian $(20-10 \mathrm{ka})$ based on 10 luminescence dates (between 18 and $11 \mathrm{ka}$ ) and four radiocarbon dates (between 13.1 and $14.9 \mathrm{ka}$ cal $\mathrm{BP}$ ) (Houmark-Nielsen et al., 2001).

Our current understanding of the LGM climate in the area farther to the southwest is based on a number of new sequences investigated in the southern Vaga valley and the Volodga area inside and outside the LGM limit (Fig. 15) and by previously published data from the Puchka and Tatischevo Lake sequences (Arslanov et al., 1970; Semenenko et al., 1981). At the Puchka section $\left(59.70^{\circ} \mathrm{N}, 39.33^{\circ} \mathrm{E}\right)$ a peat horizon within the subtill lacustrine formation has been radiocarbon dated to $21 \mathrm{ka}$ BP (Arslanov et al., 1970). Pollen and plant macrofossils from this sequence reflect a treeless Arctic and subarctic vegetation during the early LGM. Important information on the long-term climatic evolution has been obtained from a sediment core from the drained Tatischevo Lake (First of May Factory, $56.37^{\circ} \mathrm{N}, 37.19^{\circ} \mathrm{E}$ ), located $300 \mathrm{~km}$ southeast of the LGM ice-sheet limit. This core contains a nearly continuous lacustrine record covering the Eemian and Weichselian periods (Semenenko et al., 1981). Mineralogical, pollen, plant-macrofossil and faunal data show 


\section{INSIDE LGM MARGIN}

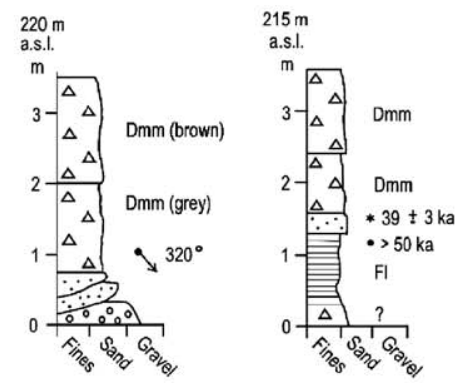

NYANDOMA SECTIONS

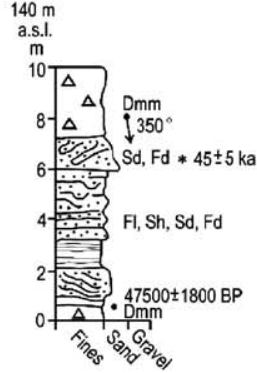

SHADRINA SECTION

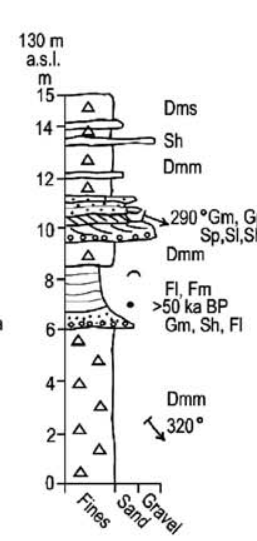

PUCHKA-2 SECTION

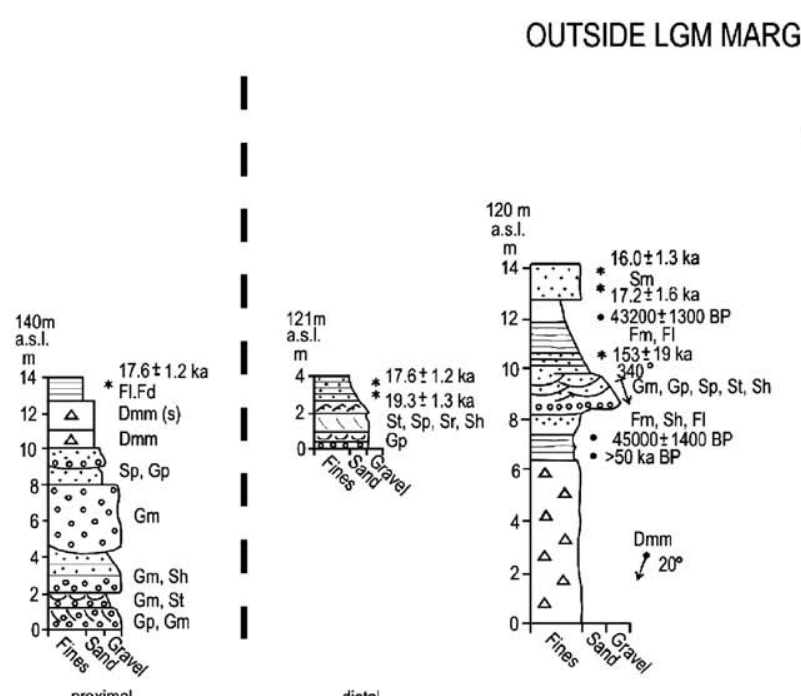

proximal

\section{KIRILLOV PIT}

distal

Sandur delta
Composite log

\section{Sandur delta
Composite log}

\section{FACIES CODES}

DMS = DIAMICTON MATRIX-SUPPORTED STRATIFIED

Dmm $=$ DIAMICTON MATRIX-SUPPORTED MASSIVE
$G m=$ GRAVEL MATRIX-SUPPORTED STRATIFIED $G p=$ GRAVEL PLANAR CROSS-BEDDED $G d=$ GRAVELLEFORMED

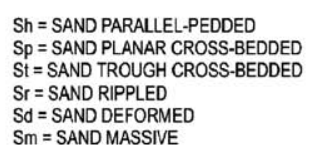

\section{FI = FINES LAMINATED $F m=$ FINES MASSIVE
$F d=$ FINES DEFORMED}

som.

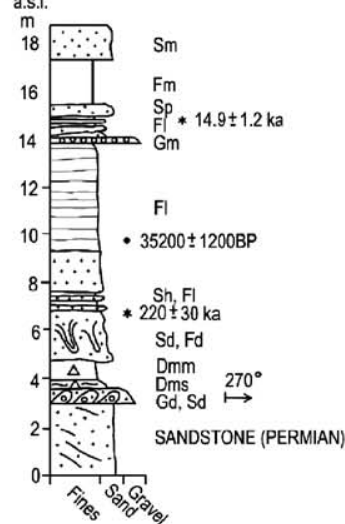

VAGA SECTION

Fig. 15. Representative sediment logs inside and outside the LGM margin in the SE flank of the Scandinavian Ice Sheet in Nyandoma—Vaga and Lake Kubenskoye areas (see Fig. 1 for locations) The topmost diamicton inside the LGM margin represents till deposited during the Late Weichselian. Two OSL dates in the distal part of Kirillov pit indicate that glaciofluvial outwash was laid down ca $19 \mathrm{ka}$ BP. 
that between 27 and $19 \mathrm{ka}$ BP sedimentation occurred under progressively cooling climatic conditions. However, the analysed pollen spectra also suggest that the relatively arid environment during the Late Weichselian was interrupted by more humid conditions around $19 \mathrm{ka}$ BP. The lake dried out completely after $19 \mathrm{ka}$ BP during the LGM, when a break in sedimentation is recorded. According to Faustova (1984) a tundra-steppe landscape covered the NW Russian Plains during the LGM. Beetle remains suggest that the climatic conditions were similar to those of the Arctic tundra of western Taymyr Peninsula at present (Nazarov, 1980).

As part of this study, we have investigated several sites and boreholes in the Tver, Volodga, and southern Arkhangelsk districts (Fig. 16). Three cores from the Vologda district can be biostratigraphically placed within the LGM period (Gey et al., 2001). Site N1 at Maega is represented by a sediment core $40 \mathrm{~m}$ long in which lacustrine silt and $14 \mathrm{~m}$ of clay in the upper part of the sequence are assumed to represent the Late Weichselian period. This is also the case in the lacustrine sediment cores from Davydkovo (Site N7) and Vysokovo (Site N8) (Fig. 16). The pollen diagrams from

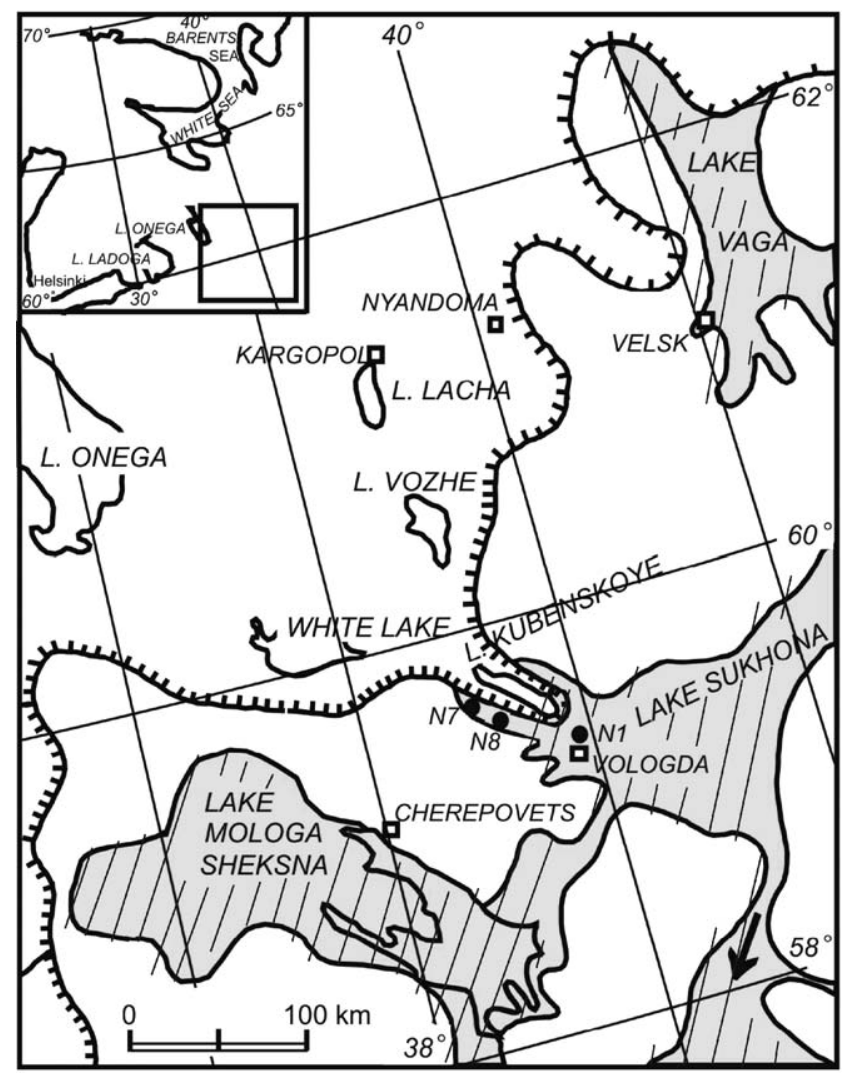

Fig. 16. A palaeoenvironmental reconstruction of the SE flank of the Scandinavian Ice Sheet during the LGM time. The ice margin at the LGM time, ice-dammed and extra-marginal lakes (Lake Vaga, Lake Sukhona, and Lake Mologa-Sheksna) and their drainage towards the Volga drainage system are shown as well as borehole sites N1, N7, N8 discussed in text. these core segments are characterized by a very high content of non-arboreal pollen (Gey et al., 2001). The upper part of the lacustrine sediments at the N7 and N8 sites contain only few pollen, which may reflect severe glaciolacustrine conditions near the ice margin at the LGM ca 19-17 ka BP (Lunkka et al., 2001). The pollen, however, indicates nearly open tundra with some patches of shrub birch during LGM time (Gey et al., 2001).

The data from sediment exposures and borehole material were used to reconstruct the palaeoenvironments in front of the ice sheet at the southeastern flank of the Scandinavian Ice Sheet during the LGM (Fig. 16). For example, in the Kubena Lake basin a lobe of the Scandinavian Ice Sheet advanced into a proglacial lake and deposited a till on top of glaciolacustrine sediments \%o NW Russian Plain. During the LGM (19-17 ka BP) ice-dammed lakes filled the Mologa-Sheksnian and Prisukhonian depressions, as well as the southern part of the Vaga River basin (Kvasov, 1979; Lunkka et al., 2001). The water level of these lakes reached ca $130 \mathrm{~m}$ a.s.l. Although it is generally believed that the climate was extremely arid during the LGM, relatively large glacial lakes existed at this time next to the ice front.

On higher ground, the aeolian cover sand is widespread on higher terrains of the NW Russian Plain, as discussed also by Velichko et al. (1984). In sections studied in the Tver, Vologda, and southern Arkhangelsk areas cover sands with fossil ice-wedge casts were frequently encountered. Since ice wedges probably only form when the annual temperature is below $-6^{\circ} \mathrm{C}$ (Péwé et al., 1969), they provide information on the climate next to the LGM ice limit. Based on OSL dated horizons where the ice-wedge casts occur, the annual temperature was well below $-6^{\circ} \mathrm{C}$ in extra-marginal areas of the Scandinavian Ice Sheet from ca $18 \mathrm{ka}$ BP (Kirillov section) to at least $15 \mathrm{ka} \mathrm{BP}$ (Vaga section). The fossil ice wedges are larger in the Vaga valley area than in the more southern sites in Tver and Vologda.

The conclusions are that Arctic and subarctic vegetation dominated the landscape in the NW Russian plains during the LGM. Even though it has previously been suggested that the climate was very dry in this region, large ice-dammed lakes did form in front of the ice sheet. These lakes suggest that melting of ice during summers was not unimportant even at that time. The existence of ice wedges indicates that the average annual temperature next to the ice margin was well below $-6^{\circ} \mathrm{C}$ at $18-15 \mathrm{ka}$ BP.

\section{Summary and discussion}

Our overview of the palaeoenvironment and climate during the Late Weichselian has been achieved by combining various data from different regions of 
northern Eurasia. The findings have then been compared with climate parameters obtained through modelling experiments. Even though all different proxy data are not directly comparable, the records indicate that the environmental conditions changed dramatically before and/or parallel with the growth of ice sheets between 25 and $20 \mathrm{ka}$, resulting in a generally colder and drier environment. However, this climate change may not have been synchronous from east to west, and the environmental responses were apparently not identical in all regions.

\subsection{Middle Weichselian climate}

Various lines of proxy evidence from the Bykovsky Peninsula near the Lena Delta (pollen, seeds, beetles, ice-wedge isotopes, etc.) suggest that the climate in the Laptev Sea region during the Middle Weichselian was of extremely continental type. It was characterized by low precipitation throughout the year and a thin snow cover. Winters were very cold, but summers were warmer than present, especially between 45 and $35 \mathrm{ka}$ BP. A clear trend to cooler summers during the late part of the Middle Weichselian (35-24 ka BP) is well documented by fossil-insect assemblages as well as by palaeobotanical records (Andreev et al., 2002a, b; Kienast, 2002; Sher et al., in preparation). A few spells of lower summer temperature during the Middle Weichselian are still to be verified by more detailed studies. Minor variations in the composition of the insect and pollen spectra may reflect changes in available moisture but could be of local significance. The continuous sequence from the Bykovsky Peninsula so far does not support the existing model of the "Karginsky interglacial", with three warm and two cold intervals (Kind, 1974), which was probably inferred from too young radiocarbon dates obtained on Eemian sediments (Astakhov, 2001). It also gives no indication of a significant northwards advance of forest, or even forest-tundra, during the Middle Weichselian, as recognized in Siberian regions farther to the east and southeast (Anderson and Lozhkin, 2001).

A relatively warm summer climate is inferred also for the regions farther to the west. On central Taymyr the pollen and plant macrofossils reflect a tundra-steppe vegetation whereas a forest-tundra environment may have existed on the southern part of the North Siberian Plain. Even the high Arctic areas of Severnaya Zemlya, which today are mostly covered by glaciers, seem to have been vegetated during this period, presumably by a kind of tundra-steppe vegetation. Open spruce forests with larch trees were growing along the middle courses of the Yenisei River on the West Siberian Plain, whereas the landscape in northernmost European Russia was a sparsely inhabited wind-swept semi-desert. In the Pechora Lowland humans were present around $36 \mathrm{ka}$ $\mathrm{BP}$ and around 29-28 ka BP, as demonstrated by finds from the Palaeolithic sites Mamontovaya Kurya and Byzovaya. All over the Eurasian Arctic numerous and varied large mammals were roaming the landscapes, including mammoth, horse, bison, woolly rhinoceros, reindeer, musk-ox, bear, and several other species. Solid permafrost did, however, prevail throughout the Middle Weichselian interstadial, at least in Siberia. This implies that even though the summers were relatively warm, the winters were much colder than today.

\subsection{Late Weichselian climate}

The proxy data from European Russia and Siberia indicate that a progressive cooling started around $30 \mathrm{ka}$ $\mathrm{BP}$, or around $35 \mathrm{ka} \mathrm{BP}$ in the east (Laptev Sea region). In spite of a very cold climate, reduced precipitation prevented glacier growth in the Siberian Arctic. The continental climate in the east was enhanced also by the northwards shift in the position of the coastline due to the falling global sea level. Later, during the LGM, the shoreline was located near the shelf margin at the present $80-100 \mathrm{~m}$ b.s.l., some $500 \mathrm{~km}$ to the north of the present coastline (Romanovskii et al., 2001). In the Laptev Sea region, the late Middle Weichselian trend to cooler summers progressed, and by $22 \mathrm{ka} \mathrm{BP}$ (beginning of the LGM) resulted in the total elimination of steppe insects and a notable reduction of mammoth populations. Mammoths in the Laptev Sea area reached lowest numbers by about $16 \mathrm{ka}$ BP. However, due to the high continentality, the summer heat supply to the ground remained relatively good, and summer temperature, though lower than before, was probably still higher than today. Grass/herb vegetation became less dense (cold tundra-steppe), but could still support the grazers, and even included some thermophilic plants (Sher et al., in preparation; Kienast, 2002). Thus, even at the peak of the LGM, mammoths and other grazers were still able to survive all over the exposed shelf land. The plantmacrofossil and pollen records also indicate that the Taymyr Peninsula was affected by a change to a more continental climate at this time. Temperatures up to $5^{\circ}$ colder than today and annual precipitation ca $100 \mathrm{~mm}$ less than at present during the LGM were reconstructed from the northern Taymyr Peninsula palynological records (Andreev et al., 2003).

With the exception of the Laptev Sea region, the climate during the early stage of the Late Weichselian was not very dry. On Severnaya Zemlya the data from Changeable Lake suggest that relative humid conditions prevailed until about $23 \mathrm{ka}$ BP. In West Siberia, the Middle Weichselian interstadial was followed by a cool but relatively humid period between 24 and $20 \mathrm{ka}$ BP. In the Pechora Lowland the generally treeless, tundrasteppe landscape was humid enough to support fertile river valleys with almost the same water discharge as today until at least 24-23 ka BP. During this period a 
rapid build-up of the ice sheets occurred along the eastern margin of the Norwegian Sea.

The currently available data indicate that during the LGM the Barents-Kara Sea Ice Sheet terminated seaward off the present-day coastline, on the Barents and Kara Sea shelves (Gataullin et al., 2001). Only the northwesternmost fringe of the Taymyr Peninsula was probably inundated by a thin and probably short-lived ice tongue, probably emanating from the higher Barents-Kara Sea Ice Sheet farther west (Alexanderson et al., 2002; Svendsen et al., 2004b). However, it is noteworthy that the glaciers on Severnaya Zemlya were not significantly larger than today and that only short mountain glaciers could exist in the Polar Urals.

As inferred by the numerical model experiments, the geological record confirms that the climate became extremely dry and cold in all areas of the Eurasian Arctic at the peak of the LGM glaciation. From the period $20-15 \mathrm{ka}$ BP a widespread deposition of inorganic aeolian sediments was recorded in both Siberia and European Russia. Results from General Circulation Modelling (GCM) suggest that the European part of northern Russia and Siberia were affected by a flow of cold and dry winds coming off the Barents-Kara Sea and Scandinavian Ice Sheets and resulting in polar desert conditions across the landmasses adjacent to the Kara Sea. It is interesting to note that the GCM results are supported by the spatial pattern of aeolian deposits, showing predominant wind directions from $\mathrm{W}$ and $\mathrm{N}$ in the central parts of the plain and from WSW in the S of West Siberia (Astakhov, 1992).

Extremely low winter temperatures across the Eurasian continent during the LGM are suggested by the occurrence of ice-wedge casts as far south as $52^{\circ} \mathrm{N}$ in West Siberia. At this time the Arctic landscapes were vegetated by discontinuous tundra-steppe plant communities. On the basis of pollen data, it has been inferred that the mean-annual temperatures in the central part of the West Siberian Plain were $8-10^{\circ} \mathrm{C}$ lower than present (Arkhipov et al., 1980), and oxygenisotope values from ice wedges on Yamal suggest that winter temperatures in this part of the Arctic were 6-9 $9^{\circ}$ lower than today (Vasilchuk, 1992). The distribution of ice wedges on the NW Russian Plain tell us that the mean-annual temperature along the eastern margin of the Scandinavian Ice Sheet was well below $-6^{\circ} \mathrm{C}$ between 18 and $15 \mathrm{ka} \mathrm{BP}$. Based on pollen data it has been calculated that the winter and summer temperatures in this region were depressed by as much as $20-29^{\circ}$ and $5-11^{\circ}$, respectively, and that the precipitation rates were only a third of the present values (Tarasov et al., 1999).

The numerical model experiments suggest significantly higher LGM temperatures for the NW Russian Plain along the southeastern margin of the Scandinavian Ice Sheet, as compared to the Siberian Arctic. This implies that the Scandinavian Ice Sheet was affected by considerable surface ablation, and the documented existence of proglacial lakes along the Fennioscandian ice margin here seems to confirm this.

A sharp climatic turnover to warmer summers started in the east as early as around $15 \mathrm{ka}$ BP. In the Laptev Sea area, it is marked by the recovery of steppe insects and the establishment of the more productive variants of tundra-steppe, which resulted in a short but high peak in mammoth numbers (Sher et al., in preparation). The climate, however, remained very dry, with cold winters. This rather short phase of increased biological productivity (15-12.5 ka BP) evidently predated the interval of favourable climate recorded farther west as the Bølling-Allerød interstadial (ca 13-11 ka BP). The end Weichselian increase in summer temperature could have triggered initial thermokarst processes in the eastern shelf lands. But it was not until $12.5 \mathrm{ka}$ BP, when the climate became more humid, that a general degradation of permafrost started, accompanied by a dramatic change in vegetation from tundra-steppe to wet tundra and forest tundra, which greatly contributed to the virtual extinction of the megafauna.

The revealed climatic change around $15-13 \mathrm{ka}$ BP is consistent with the documented timing of general deglaciation, and with the flooding of the Laptev Sea shelf (Hubberten and Romanovskii, 2001). A major deglaciation of the central Barents Sea shelf took place at this time, and northwestern Taymyr rapidly became ice-free.

\section{Conclusions}

The last (LGM) glaciation in northern Eurasia was initiated by a progressive cooling that started at around $30 \mathrm{ka} \mathrm{BP}$. The ice growth in Scandinavia and the western Barents Sea region was enhanced by a maritime type of climate, causing relatively high precipitation rates along the western flank of the developing ice sheets. The icesheet modelling experiments calculate rates of ice accumulation in the order $100-200 \mathrm{~mm} \mathrm{yr}^{-1}$ around the western margin of the Barents Sea, increasing to over $600 \mathrm{~mm} \mathrm{yr}^{-1}$ along the western margin of Scandinavia.

In the Eurasian Arctic, the climate became extremely dry and cold during the period $20-15 \mathrm{ka}$ BP when the ice sheets there reached their maximum LGM positions. It is inferred that the precipitation rates in the Siberian Arctic along the Kara Sea were less than $50 \mathrm{~mm} \mathrm{yr}^{-1}$ during the LGM, which is similar to the present conditions in central East Antarctica. In the whole Eurasian Arctic, the LGM glaciation was considerably less extensive than it had been during the early Middle Weichselian glacial events. 
In the eastern part of the region (the Laptev Sea area) due to the extensive recession northwards of the shoreline (lowered sea level), the summer effect of climatic continentality overrode the general cooling of climate during the LGM and provided more favourable biotic conditions in high latitudes. The LGM periglacial environment on the eastern shelf lands was characterized by a higher summer temperature, but much lower winter temperature, than at present.

The latest Weichselian climatic change around $15 \mathrm{ka}$ BP occurred in all areas of the Eurasian Arctic, but the dynamics of climate warming and increasing humidity were different in the western (glacially affected) and eastern (periglacial) areas.

\section{Acknowledgements}

This paper was compiled by participants of the "Eurasian Ice Sheet" project which was funded by the European Union (EU), Contract No. ENV4-CT970563. This project was a major contribution to the European Science Foundation (ESF) programme "QUEEN" (Quaternary Environment of the Eurasian North). In addition, major funding was obtained through national founding agencies like the German Ministry of Science and Technology (Projects: "Taymyr" and "System Laptev Sea 2000"), the Russian Ministry for Technology and Research, the Russian Foundation for Basic Research, the research council of Norway (PECHORA project), the Swedish Natural Sciences Research Council and the Swedish Polar Research Secretariat. Guido Grosse (AWI Potsdam) has redrawn most of the figures. We thank all institutions and individuals who made this investigation possible with their support.

\section{References}

Alexanderson, H., Hjort, Ch., Möller, P., Antonov, O., Pavlov, M., 2001. The North Taymyr ice-marginal zone, Arctic Siberia-a preliminary overview and dating. Global and Planetary Change 31, $427-445$.

Alexanderson, H., Adrielsson, L., Hjort, C., Möller, P., Antonov, O., Eriksson, S., Pavlov, M., 2002. The depositional history of the North Taymyr ice-marginal zone, Siberia - a land system approach. Journal of Quaternary Sciences 17, 361-382.

Anderson, P.M., Lozhkin, A.V., 2001. The Stage 3 interstadial complex (Karginski/Middle Wisconsinan interval) of Beringia: variations in palaeoenvironments and implications for palaeoclimatic interpretations. Quaternary Science Reviews 20, 93-125.

Andreev, A.A., Peteet, D.M., Tarasov, P.E., Filimonova, L., Romanenko, F.A., Sulerzhitsky, L.D., 2001. Late Pleistocene interstadial environment on Faddeyevskiy Island, East Siberian Sea, Russia. Arctic, Antarctic, and Alpine Research 33, 28-35.

Andreev, A.A., Siegert, Ch., Klimanov, V.A., Derevyagin, A.Yu., Shilova, G.N., Melles, M., 2002a. Late Pleistocene and Holocene vegetation and climate changes in the Taymyr Lowland, northern
Siberia reconstructed from pollen records. Quaternary Research 57, 138-150.

Andreev, A.A., Schirrmeister, L., Siegert, Ch., Bobrov, A.A., Demske, D., Seiffert, D., Hubberten, H.-W., 2002b. Paleoenvironmental changes in Northeastern Siberia during the Late Quaternaryevidences from pollen records of the Bykovsky Peninsula. Polarforschung 70, 13-25.

Andreev, A.A., Tarasov, P.E., Siegert, Ch., Ebel, T., Klimanov, V.A., Melles, M., Bobrov, A.A., Dereviagin, A.Yu., Lubinski, D.J., Hubberten, H.-W., 2003. Late Pleistocene and Holocene vegetation and climate on the northern Taymyr Peninsula, Arctic Russia. Boreas 32, 484-505.

Arkhipov, S.A., Astakhov, V.I., Volkov, I.A., Volkova, V.S., 1980. Paleogeography of the West Siberian Plain at the Late Zyryanka glaciation maximum (Paleogeografia Zapadno-Sibirskoi ravniny v maximum pozdnezyryanskogo oledeneniya). Nauka, Novosibirsk, 109pp. (in Russian).

Arslanov, Kh.A., Auslender, V.G., Gromova, L.I., Zubkov, A.I., Khomutova, V.I., 1970. Paleogeography and absolute age of the Valday glacial maximum near lake Kubena. Doklady Akademii Nauk SSSR 195, 1395-1398 (in Russian).

Arslanov, Kh.A., Lavrov, A.S., Potapenko, L.M., Tertychnaya, T.V., Chernov, S.B., 1987. New data on geochronology and paleogeography of the Late Pleistocene and Early Holocene in the northern Pechora Lowland. In: Punning, J.M., et al. (Ed.), Novye Dannye Po Geokhronologii Chetvertichnogo Perioda. Nauka, Moscow, pp. 101-111 (in Russian).

Astakhov, V.I., 1989. Late Pleistocene Sedimentary Environments in the Center of West Siberia, Vol. 657. Trudy Instituta Geologii Geofisiki, Nauka, Novosibirsk, pp. 118-126 (in Russian).

Astakhov, V.I., 1992. The last glaciation in West Siberia. Sveriges Geologiska Undersökning, Ser. Ca 81, Uppsala, pp. 21-30.

Astakhov, V., 1998. The last ice sheet of the Kara Sea: terrestrial constraints on its age. Quaternary International 45/46, 19-29.

Astakhov, V.I., 2001. Stratigraphic framework for the Upper Pleistocene of the Russian Arctic: changing paradigms. Global and Planetary Change 31 (1-4), 281-293.

Astakhov, V.I., Isayeva, L.L., 1988. The 'Ice Hill': an example of retarded deglaciation in Siberia. Quaternary Science Reviews 7, 29-40.

Astakhov, V.I., Svendsen, J.I., 2002. Age of remnants of a Pleistocene glacier in Bol'shemel'skaya Tundra. Doklady Earth Sciences ISSN 1028-334X 384 (4), 468-472 Translated from Doklady Akademii Nauk, 2002, 384(4), 534-538.

Astakhov, V.I., Svendsen, J.I., Matiouchkov, A., Mangerud, J., Maslenikova, O., Tveranger, J., 1999. Marginal formations of the last Kara and Barents ice shelves in northern European Russia. Boreas 28, 23-45.

Atlas Arktiki, 1985. Central Administration for Geodesy and Cartography of the Ministerial Council of the USSR, Moscow, 1985, 204pp. (in Russian).

Bauch, H.A., Mueller-Lupp, T., Taldenkova, E., Spielhagen, R.F., Kassens, H., Grootes, P.M., Thiede, J., Heinemeier, J., Petryashov, V.V., 2001. Chronology of the Holocene transgressions at the North Siberian Margins. Global and Planetary Change 31, $125-139$

Baulin, V.V., Chekhovsky, A.L., Sukhodolsky, S.Ye., 1981. Main stages of development of perennially frozen rocks in the northeastern European USSR and in West Siberia. In: Melnikov, P.I. (Ed.), Istoriya Razvitiya Mnogoletnmiorzlykh Porod Evrazii. Nauka, Moscow, pp. 41-60 (in Russian).

Bentley, C.R., 1987. Antarctic ice streams: a review. Journal of Geophysical Research 92, 8843-8858.

Biryukov, V.V., Faustova, M.A., Kaplin, P.A., Pavlidis, Y.A., Romanova, E.A., Velichko, A.A., 1988. The palaeogeography of Arctic Shelf and coastal zone of Eurasia at the time of the last 
glaciation. Palaeogeography, Palaeoclimatology, Palaeoecology 68, $117-125$.

Bobrov, A.A., Siegert, C., Andreev, A.A., Schirrmeister, L., 2003. Testataceans (Protozoa: Testacea) in Quaternary permafrost sediments of Bykovsky Peninsula, Arctic Yakutia. Biology Bulletin 30, 191-206.

Bolikhovsky, V.F., 1987. Yedoma sediments in West Siberia. In: Punning, J.M. (Ed.), Novye Dannye Po Geokhronologii Chetvertichnogo Perioda. Nauka, Moscow, pp. 128-136 (in Russian).

Bolshiyanov, D.Yu., Makeyev, V.M., 1995. The Severnaya Zemlya archipelago: glaciation, environmental history (Arkhipelag Severnaya Zemlya: oledeneniye, istoria razvitia prirodnoi sredy). Gidrometeoizdat, St. Petersburg, 216pp. (in Russian).

Denton, G.H., Hughes, T.J., 1981. The Arctic ice sheet: an outrageous hypothesis. In: Denton, G.H., Hughes, T.J. (Eds.), The Last Great Ice Sheets. Wiley, New York.

Dereviagin, A.Yu., Chizhov, A.B., Brezgunov, V.S., Siegert, Ch., Hubberten, H.-W., 1999. Isotopic composition of ice wedges of Cape Sabler (Lake Taymyr). Earth Cryosphere 3, 41-149 (in Russian).

Devyatova, E.I., 1982. Late Pleistocene environment and its impact on human population in the Severnaya Dvina basin and in Karelia (Prirodnaya sreda pozdniego pleistotsena i yeyo vliyanie na razvitie cheloveka v Severodvinskom basseine i v Karelii). Karelia, Petrozavodsk, 156pp. (in Russian).

Dolvik, T., Hjelle, T., Mangerud, J., Matiouchkov, A., 2002. Weichselian glaciations in the Polar Ural Moutains. Quaternary Environment of the Eurasian North (QUEEN), Sixth Workshop, Spiez, Switzerland, 24-28 May 2002, p. 11.

Dowdeswell, J.A., Siegert, M.J., 1999. Ice-sheet numerical modeling and marine geophysical measurements of glacier-derived sedimentation on the Eurasian Arctic continental margins. Geological Society of America Bulletin 111, 1080-1097.

Faustova, M.A., 1984. Late Pleistocene glaciation of European USSR. In: Velichko, A.A. (Ed.), Late Quaternary Environments of the Soviet Union. University of Minnesota Press, Minneapolis, pp. $3-12$.

Forman, S.L., Ingólfsson, O., Gataullin, V., Manley, W.F., Lokrantz, H., 1999. Late Quaternary stratigraphy of western Yamal Peninsula, Russia: new constraints on the configuration of the Eurasian Ice Sheet. Geology 27, 807-810.

Gataullin, V., Mangerud, J., Svendsen, J.I., 2001. The extent of the Late Weichselian ice sheet in the southeastern Barents Sea. Global and Planetary Change 31 (1-4), 451-472.

Gey, V., Saarnisto, M., Lunkka, J.P., Demidov, I., 2001. Mikulino and Valdai paleoenvironments in the Vologda area, NW Russia. Global and Planetary Change 31, 347-366.

Glen, J.W., 1955. The creep of polycrystalline ice. Proceedings of the Royal Society of London A228, 519-538.

Grosswald, M.G., 1998. Late-Weichselian ice sheets in Arctic and Pacific Siberia. Quaternary International 45/46, 3-18.

Grosswald, M.G., Hughes, T.J., 1995. Paleoglaciology's grand unsolved problem. Journal of Glaciology 41, 313-332.

Grosswald, M.G., Hughes, T.J., 2002. The Russian component of an Arctic ice sheet during the Last Glacial Maximum. Quaternary Science Reviews 21, 121-146.

Grosswald, M.G., Kotlyakov, V.M., 1969. Present-day glaciers in the USSR and some data on their mass balance. Journal of Glaciology 8, 9-21.

Hahne, J., Melles, M., 1997. Late- and post-glacial vegetation and climate history of the south-western Taymyr Peninsula, central Siberia, as revealed by pollen analyses of a core from Lake Lama. Vegetation History and Archaeobotany 6, 1-8.

Hahne, J., Melles, M., 1999. Climate and vegetation history of the Taymyr Peninsula since Middle Weichselian time-palynological evidence from lake sediments. In: Kassens, H., Bauch, H.A.,
Dmitrenbko, I.A., Eicken, H., Hubberten, H.-W., Melles, M., Thiede, J., Timokhov, L.A. (Eds.), Land-Ocean Systems in the Siberian Arctic: Dynamics and History. Springer, Berlin, pp. 361-376.

Halvorsen, L.S., 2000. Palaeovegetation and environment during Weichselian stadials and interstadials at Mamontovaya Kurja and Sokolova in the Pechora basin, northern Russia. Unpublished Cand. Scient. (Master) Thesis, University of Bergen, 68pp.

Henriksen, M., Mangerud, J., Matiouchkov, A., Paus, A., Svendsen, J.I., 2003. Lake stratigraphy implies an 80,000 year delayed melting of buried dead ice in northern Russia. Journal of Quaternary Science 18, 1-17.

Houmark-Nielsen, M., Demidov, I., Funder, S., Grøsfjeld, K., Kjær, K.-H., Larsen, E., Lavrova, N., Lyså, A., Nielsen, J.K., 2001. Early and middle Valdaian glaciations, ice dammed lakes and periglacial interstadials in northwest Russia: new evidence from the Pyozo river area. Global and Planetary Change 31, 215-237.

Hubberten, H.-W., Romanovskii, N.N., 2001. Terrestrial and offshore permafrost evolution of the Laptev Sea region during the last Pleistocene-Holocene glacial-eustatic cycle. In: Paepe, R., Melnikov, V. (Eds.), Permafrost Response on Economic Development, Environmental Security and Natural Resources. Proceedings of the NATO-ARW, Novosibirsk. Kluwer, Dordrecht, 1998, pp. 43-60.

Hughes, T., 1985. The great Cenozoic ice sheet. Palaeogeography, Palaeoclimatology, Palaeoecology 50, 9-43.

Huybrechts, P., Payne, A., the EISMINT Intercomparison Group, 1996. The EISMINT benchmarks for testing ice-sheet models. Annals of Glaciology, 23, 1-12.

Isayeva, L.L., Kind, N.V., 1982. On contradictions in interpretation of the scales of the last Late Pleistocene glaciation. In: Kind N.V., Leonov V.N. (Eds.), Antropogen. Taimyra, Nauka, Moscow, pp. 165-168 (in Russian).

Isayeva, L.L., Andreyeva, S.M., Bardeyeva, M.A., Kolpakov, V.V., Laukhin, S.A., Reverdatto, M.V., Rindzyunskaya, N.M., Shofman, I.L., 1993. Central Siberia. In: Velichko A, A. (Ed.), Razvitie landshaftov i klimatov Severnoi Evrazii. Pozdniy pleistotsengolotsen, 1. Paleogeografia. Nauka, Moscow, pp. 46-59 (in Russian).

Kaplyanskaya, F.A., Tarnogradsky, V.D., 1974. The Middle and Lower Pleistocene of the lower Irtysh area (Sredny i nizhny pleistotsen nizovyev Irtysha). Nedra, Leningrad, 160pp. (in Russian).

Kienast, F., 2002. Die Rekonstruktion der spätquartären Vegetationsund Klimageschichte der Laptewsee-Region auf der Basis botanischer Großrestuntersuchungen. Ph.D. Dissertation, Potsdam University, 116pp.

Kienast, F., Siegert, C., Dereviagin, A.Yu., Mai, H.D., 2001. Climatic implications of Late Quaternary plant macrofossil assemblages from the Taymyr Peninsula, Siberia. Global and Planetary Change 31, 265-281.

Kind, N.V., 1974. Late Quaternary geochronology according to isotope data (Geokhronologia pozdniego antropogena po izotopnym dannym). Nauka, Moscow, 255pp. (in Russian).

Kleiber, H.P., Niessen, F., Weiel, D., 2001. The Late Quaternary evolution of the western Laptev Sea continental margin, Arctic Siberia-implications from sub-bottom profiling. Global and Planetary Change 31, 105-124.

Knies, J., Kleiber, H.-P., Matthiessen, J., Müller, C., Nowaczyk, N., 2001. Marine ice-rafted debris records constrain maximum extent of Saalian and Weichselian ice-sheets along the northern Eurasian margin. Global and Planetary Change 31, 45-64.

Krivonogov, S.K., Bakhareva, V.A., Kim, Yu.V., Orlova, L.A., Skabichebskaya, N.A., 1993. New data on stratigraphy and paleogeography of the Late Pleistocene of the Surgut Poles'ye. Geologiya i geofizika 3, 24-37 (in Russian). 
Kuzmina, S., 2001. Quaternary insects of the coastal lowlands of Yakutia. Ph.D. Dissertation in Biology, Paleontological Institute RAS, 481pp. (in Russian).

Kuznetsova, T.V., Sulerzhitsky, L.D., Schirrmeister, L., Siegert, Ch., Hubberten, H.-W., Sher, A.V., 2001. Late Quaternary mammals of the Laptev Shelf land and their environment. European Union of Geosciences XI, Strasbourg, France, April 8-12, 2001 (Abstract).

Kvasov, D.D., 1979. The Late Quaternary history of large lakes and inland seas of eastern Europe. Annales Academiae Scientiarum Fennicae, Series A (Helsinki) 127, 71.

Landvik, J.I., Bondevik, S., Elverhøi, A., Fjeldskaar, W., Mangerud, J., Salvigsen, O., Siegert, M.J., Svendsen, J.I., Vorren, T.O., 1998. The Last Glacial Maximum of Svalbard and the Barents Sea area: ice sheet extent and configuration. Quaternary Science Review 17, 43-75.

Larsen, E., Lyså, A., Demidov, I., Funder, S., Houmark-Nielsen, M., Kjær, K.H., Murray, A.S., 1999. Age and extent of the Scandinavian Ice Sheet in northwest Russia. Boreas 28, 115-132.

Lunkka, J.P., Saarnisto, M., Gey, V., Demidov, I., Kiselova, V., 2001. The extent and timing of the Last Glacial Maximum in the southeastern sector of the Scandinavian Ice Sheet. Global and Planetary Change 31, 407-525.

Lyså, A., Demidov, I., Houmark-Nielsen, M., Larsen, E., 2001. Late Pleistocene stratigraphy and sedimentary environment of the Arkhangelsk area, northwest Russia. Global and Planetary Change 31, 179-199.

Makeyev, V.M., Bolshiyanov, D.Yu., 1986. Characteristics of glacial sediments on the Severnaya Zemlya Archipelago. In: Kainozoi shel'fa i ostrovov Rossiiskoi Arktiki. Leningrad, pp. 127-132, (in Russian).

Makeyev, V.M., Pitulko, V.V., Kasparov, A.K., 1993. The natural environment of the De Long Archipelago and ancient man in the Late Pleistocene and Early Holocene. Polar Geography and Geology 17, 55-63.

Mangerud, J., Dokken, T., Hebbeln, D., Heggen, B., Ingolfsson, O., Landvik, J.Y., Mejdahl, V., Svendsen, J.I., Vorren, T.O., 1998. Fluctuations of the Svalbard-Barents Sea ice sheet during the last 150,000 years. Quaternary Science Reviews 17, 11-42.

Mangerud, J., Svendsen, J.I., Astakhov, V.I., 1999. Age and extent of the Barents and Kara ice sheets in northern Russia. Boreas 28, 46-80.

Mangerud, J., Astakhov, V., Svendsen, J.I., 2002. The extent of the Barents-Kara ice sheet during the Last Glacial Maximum. Quaternary Science Reviews 21, 111-119.

Meyer, H., Dereviagin, A., Siegert, Ch., Hubberten, H.-W., $2002 a$. Paleoclimate studies on Bykovsky Peninsula, North Siberiahydrogen and oxygen isotopes in ground ice. Polarforschung 70, $37-51$.

Meyer, H., Dereviagin, A.Yu., Siegert, Ch., Schirrmeister, L., Hubberten, H.-W., 2002b. Paleoclimate reconstruction on Big Lyakhovsky Island, North Siberia-hydrogen and oxygen isotopes in ice wedges. Permafrost and Periglacial Processes 13, 91-105.

Möller, P., Bolshiyanov, D.Yu., Bergsten, H., 1999. Weichselian geology and palaeo-environmental history of the central Taymyr Peninsula, Siberia, indicating no glaciation during the last global glacial maximum. Boreas 28, 92-114.

Nazarov, V.I., 1980. The insect fauna of the Late Pleistocene of Byelorussia. In: Paleontology. Transactions of the Scientific Meetings of the Paleontology Section of the Moscow Society of Nature Researchers for 1977-1978, Moscow (in Russian).

Paus, Aa., Svendsen, J.I., Matioushkov, A., 2003. Late weichselian (valdaian) and holocene vegetation and environmental history of the timan ridge, european arctic russia. Quaternary Science Reviews 22, 2285-2302.

Pavlidis, Yu.A., Dunayev, N.N., Shcherbakov, F.A., 1997. The Late Pleistocene of the Arctic Eurasian ice shelves. Quaternary International 41/42, 3-9.
Pavlov, P., Indrelid, S., 2000. Human occupation in northeastern Europe during the period 35,000 until 18,000 B.P. In: Reobroeks, W., Mussi, M., Svoboda, J., Fennema, K. (Eds.), Hunters of the Golden Age; the Mid Upper Paleolithic of Eurasia. Leiden University, pp. 165-172.

Pavlov, P., Svendsen, J.I., Indrelid, S., 2001. Human presence in the European Arctic nearly 40,000 years ago. Nature 413, 64-67.

Peltier, W.R., 1994. Ice age paleotopography. Science 265, 195-201.

Péwé, T.L., Church, R.E., Andersen, M.J., 1969. Origin and paleoclimatic significance of large-scale patterned ground in the Donnelly Dome Area, Alaska. Geological Society of America, Special Paper 103, 87.

Popov, A.I., 1962. Cover silts and polygonal relief of Bolshezemelskaya Tundra. In: Popov, A.I. (Ed.), Voprosy geographicheskogo merzlotovedenia i periglatsialnoi morfologii. Moscow University, pp. 109-130 (in Russian).

Raab, A., 2000. Sedimente des Changeable-Sees, OktoberrevolutionsInsel (Severnaja Zemlja) als Archive der Paläoumwelt Mittelsibiriens seit dem Frühweichsel. Ph.D. Dissertation, Potsdam University, $115 \mathrm{pp}$.

Raab, A., Melles, M., Berger, G.W., Hagedorn, B., Hubberten, H.-W., 2003. Non-glacial paleoenvironment and limiting extent of Weichselian (MIS 2-5d) ice sheets on Severnaya Zemlya (Russian High Arctic). Quaternary Science Reviews 22, 2267-2283.

Romanovskii, N.N., Gavrilov, A.V., Tumskoy, V.E., Kholodov, A.L., Siegert, C., Hubberten, H.-W., Sher, A.V., 2001. Environmental evolution in the Laptev Sea region during Late Pleistocene and Holocene. Polarforschung 67, 237-245.

Schirrmeister, L., Siegert, C., Kunitsky, V.V., Grootes, P., Erlenkeuser, H., 2002a. Late Quaternary ice-rich permafrost sequences as an archive for the Laptev Sea environment. International Journal of Geosciences (Geologische Rundschau) 91, 154-167.

Schirrmeister, L., Siegert, C., Kuznetsova, T., Kuzmina, S., Andreev, A.A., Kienast, F., Meyer, H., Bobrov, A., 2002b. Paleoenvironmental and paleoclimatic records from permafrost deposits in the Arctic region of northern Siberia. Quaternary International 89, 97-118.

Semenenko, L.T., Alyoshinskaya, Z.V., Arslanov, Kh.A., Valuyeva, M.N., Krasnovskaya, F.I., 1981. The key section of the Upper Pleistocene at the 1st of May Factory, Dmitrov District of the Moscow Region (sediments of former Lake Tatishchevo). In: Shick, S.M. (Ed.), Novye dannye po stratigrafii i paleogeografii verkhnego pliotsena i pleistotsena tsentralnykh rayonov Yevropeiskoi chasti SSSR, Moscow, pp. 121-136 (in Russian).

Sher, A., Kuzmina, S., Kiselyov, S., Lister, A., 2003. Tundra-steppe environment in arctic Siberia and the evolution of the woolly mammoth. In: Storer, J.E. (Ed.), The Third International Mammoth Conference, Yukon, Canada, May 24-29, 2003, Government of Yukon Palaeontology Program, Occasional Papers in Earth Sciences 5, 136-142.

Siegert, C., Dereviagin, A.Yu., Shilova, G.N., Hermichen, W.-D, Hiller, A., 1999. Paleoclimatic evidences from permafrost sequences in the Eastern Taymyr lowland. In: Kassens, H., Bauch, H.A., Dmitrenbko, I.A., Eicken, H., Hubberten, H.-W., Melles, M., Thiede, J., Timokhov, L.A. (Eds.), Land-Ocean Systems in the Siberian Arctic: Dynamics and History. Springer, Berlin, pp. 477-499.

Siegert, C., Schirrmeister, L., Babiy, O., 2002. The sedimentological, mineralogical and geochemical composition of Late Pleistocene deposits from the Ice complex on the Bykovsky Peninsula, northern Siberia. Polarforschung 70, 3-11.

Siegert, M.J., Marsiat, I., 2001. Numerical reconstructions of LGM climate across the Eurasian Arctic. Quaternary Science Reviews 20, 1595-1605.

Siegert, M.J., Dowdeswell, J.A., Melles, M., 1999. Late Weichselian glaciation of the Eurasian High Arctic. Quaternary Research 52, 273-285. 
Siegert, M.J., Dowdeswell, J.A., Hald, M., Svendsen, J.-I., 2001. Modelling the Eurasian Ice Sheet through a full (Weichselian) glacial cycle. Global and Planetary Change 31, 367-385.

Stein, R., Boucsein, B., Fahl, K., Garcia de Oteyza, T., Knies, J., Niessen, F., 2001. Accumulation of particulate organic carbon at the Eurasian continental margin during Late Quaternary times: controlling mechanisms and paleoenvironmental significance. Global and Planetary Change 31, 87-104.

Sulerzhitsky, L.D., 1995. Characteristics of radiocarbon chronology of the woolly mammoth (Mammuthus primigenius) of Siberia and north of East Europe. In: Baryshnikov, G. (Ed.), Studies of Pleistocene and Recent Mammals. Proceedings of the Zoological Institute, Russian Academy of Sciences, Vol. 263, pp. 163-183, Moscow (in Russian).

Sulerzhitsky, L.D., Romanenko, F.A., 1999. The "Twilight" of the mammoth fauna in the Asiatic Arctic. Ambio 28, 251-255.

Svendsen, J.I., Pavlov, P., 2004. Mamontovaya Kurya-an enigmatic, nearly 40,000 years old Palaeolithic site in the Russian Arctic. In: Zilhâo, J., d'Ericco, F. (Eds.), The Chronology of the Aurignacien and the Transitional Technocomplexes-Dating, Stratigraphies, Cultural Implications. Trabalhos de Archaeologia, Lisboa, in press.

Svendsen, J.I., Astakhov, V.I., Bolshiyanov, D.Yu., Demidov, I., Dowdeswell, J.A., Gataullin, V., Hjort, C., Hubberten, H.-W., Larsen, E., Mangerud, J., Melles, M., Möller, P., Saarnisto, M., Siegert, M.J., 1999. Maximum extent of the Eurasian Ice Sheets in the Barents and Kara Sea region during the Weichselian. Boreas 28, 234-242.

Svendsen, J.I., Gataullin, V., Mangerud, J., Polyak, L., 2004a. The glacial history of the Barents and Kara Sea region. In: Ehlers, J., Gibbard, P. (Eds.), Quaternary Glaciations - Extent and Chronology, Vol. 1 Europe. Elsevier, Amsterdam, in press.

Svendsen, J.I, Alexanderson, H., Astakhov, V.I., Demidov, I., Dowdeswell, J.A., Funder, S., Gataullin, V., Henriksen, M., Hjort, C., Houmark-Nielsen, M., Hubberten, H.W., Ingólfsson, O., Jakobsson, M., Kjær, K.H., Larsen, E., Lokrantz, H., Lunkka, J.-P., Lyså, A., Mangerud, J., Matioushkov, A., Murray, A., Möller, P., Niessen, F., Nikolskaya, O., Polyak, L., Saarnisto, M., Siegert, C., Siegert, M.J., Spielhagen, R.F., Stein, R., 2004b. Late Quaternary ice sheet history of Eurasia. Quaternary Science Reviews, this issue (doi:10.1016/j.quascirev.2003.12.008).
Tarasov, P.E., Peyron, O., Guiot, J., Brewer, S., Volkova V, .S., Bezusko, L.G., Dorofeyuk, N.I., Kvavadze, E.V., Osipova, I.M., Panova, N.K., 1999. Last Glacial Maximum climate of the former Soviet Union and Mongolia reconstructed from pollen and plant macrofossil data. Climate Dynamics 15, 227-240.

Vasilchuk, Yu.K., 1992. Oxygen Isotope Composition of Ground Ice: Application to Paleogeocryological Reconstructions (Izotopnokislorodny sostav podziemnykh ldov: opyt paleokriologicheskikh rekonstruktsiy), Vol. 1. Moscow, 420pp. (in Russian).

Vasilchuk, Yu.K., Vasilchuk, A.C., 1998. ${ }^{14} \mathrm{C}$ and ${ }^{18} \mathrm{O}$ in Siberian syngenetic ice-wedge complexes. Radiocarbon 40, 883-893.

Vasilchuk, Yu.K., van der Plicht, J., Vasilchuk, A.K., Jungner, H., Sonninen, E., 2000a. First radiocarbon datings on Late Pleistocene ice syngenetic wedges. Doklady Russian Academic Science 371, 114-117 (in Russian).

Vasilchuk, Yu.K., van der Plicht, J., Jungner, H., Sonninen, E., Vasilchuk, A.K., 2000b. First direct dating of Late Pleistocene ice wedges by AMS. Earth and Planetary Science Letters 179, 237-242.

Velichko, A.A., Bogucki, A.B., Morozova, T.D., Udartsev, V.P., Khalcheva, T.A., Tsatskin, A.I., 1984. Periglacial landscapes of the East European plain. In: Velichko, A.A. (Ed.), Late Quaternary Environments of the Soviet Union. University of Minnesota Press, Minneapolis, pp. 94-118.

Volkov, I.A., 1971. The Late Quaternary Subaerial Sedimentary Association (Pozdnechetvertichnaya subaeralnaya formatsia). Nauka, Moscow, 253pp. (in Russian).

Volkov, I.A., Zykina, V.S., 1984. Loess stratigraphy in Southwestern Siberia. In: Velichko A, A. (Ed.), Late Quaternary Environments of the Soviet Union. University of Minnesota Press, Minneapolis, pp. 119-124.

Volkov, I.A., Grosswald, M.G., Troitsky, S.L., 1978. On the proglacial drainage during the last glaciation in West Siberia. Izvestiya Academii Nauk SSSR, Seriya Geograficheskaya, 4, 25-35 (in Russian).

Yershov, E.D. (Ed.), 1988. The Geocryology of the USSR. European Territory (Geokhronologia SSSR. Evropeiskaya territoria). Nedra, Moscow, 358pp. (in Russian).

Yurtsev, B.A., 1981. Relict steppe vegetation complexes of Northern Asia (Problems of reconstruction of the cryoxerotic landscapes of Beringia). Nauka, Novosibirsk, 68pp. (in Russian). 